Mateusz Mataniak (Kraków)

\title{
Bank Krajowy Wolnego Miasta Krakowa. O nieudanych próbach jego utworzenia w latach 1833-1835
}

\section{WPROWADZENIE}

W niniejszym artykule odtworzono starania władz Wolnego Miasta Krakowa o utworzenie tzw. Banku Krajowego. Prezentowany temat nie doczekał się analizy w literaturze naukowej, stąd dla jego opracowania kluczowe znaczenie miały dokumenty źródłowe, zaczerpnięte ze zbiorów Archiwum Narodowego w Krakowie. Na wyróżnienie zasługują zwłaszcza tzw. akta senackie, stanowiące spuściznę po działalności Senatu Rządzącego, sprawującego w Rzeczypospolitej Krakowskiej „zwierzchnią władzę administracyjną” (fasc. 88 „Monety 1816-1853”, sygn. WMK V-202). Z zespołu „Archiwum Wolnego Miasta Krakowa” pochodzą także protokoły posiedzeń Zgromadzenia Reprezentantów (sejm WMK) oraz jego korespondencja z rządem. Szczególną uwagę poświęcono traktatom dwóch autorów: Hilarego Meciszewskiego i Józefa Hallera, którzy byli głównymi orędownikami idei Banku Krajowego. Ukazały się one drukiem w latach 1834-1835. Niebagatelną rolę odegrały też publikatory prawne („Dziennik Praw WMK”, „Dziennik Rządowy”) oraz krakowska prasa. Ponadto uwzględniono opracowania poświęcone dziejom bankowości na ziemiach polskich w XIX w.

Za wprowadzenie posłużyć może garść informacji o systemach bankowych, funkcjonujących w Europie pierwszej połowy XIX stulecia. Poprzedzić je musi zdefiniowanie pojęcia banku. Zgodnie z klasyczną, pochodzącą z 1932 r. definicją Feliksa Wilińskiego, bankiem określamy po prostu ,przedsiębiorstwo zajmujące się interesami pieniężnymi, kredytowymi oraz pokrewnymi tym ostatnim"1.

W ogólności można powiedzieć, że geneza banków sięga czasów starożytnych. Była ona związana z powstaniem i rozwojem pieniądza, a w dalszej kolejności z wy-

\footnotetext{
${ }^{1}$ F. Wiliński, Bank i jego organizacja, Lwów 1932 (Warszawa 1991), s. 5.
} 
pieraniem pieniądza kruszcowego przez pieniądz papierowy oraz z pojawieniem się pieniądza bezgotówkowego. Sytuacja taka wytworzyła zapotrzebowanie na instytucje pośredniczące i uwiarygodniające obrót pieniężny. Ewolucja bankowości wiąże się również z rozwojem weksla jako instrumentu przekazowego na instrument kredytowy; oprócz tego, z koncepcją pieniądza papierowego w formie biletu bankowego, a także $\mathrm{z}$ dyskontem weksli handlowych oraz upłynnianiem aktywów majątkowych (kredytowy środek płatniczy). Na dalszym etapie rozwoju pojawiły się banki emisyjne (biletowe), które otrzymywały od państwa przywilej emitowania banknotów, stając się w ten sposób pierwszymi bankami centralnymi (Bank Szwecji 1657 r., Bank Anglii 1694 r.). Wprowadzenie w XIX w. państwowego nadzoru nad działalnością banków okazało się trwałą podstawą ich egzystencji. Poszerzeniu uległ także zakres czynności bankowych: w początkowym okresie obsługiwały one rynek towarowy, następnie, w wyniku rozwoju rynków finansowych, stały się ich głównym organizatorem, uczestnikiem i kontrolerem. Pojawił się wówczas podział banków na emisyjne i komercyjne; doszło też do ich wyraźnej specjalizacji. Działalność bankowa zaczęla być traktowana jako przejaw działalności gospodarczej, dlatego też coraz ściślej określano zasady jej wykonywania².

Należy zwrócić uwagę, że banki prowadzą zazwyczaj kilka rodzajów działalności, z których jeden jest zazwyczaj dominujący, co określa charakter całej instytucji. Podstawowa klasyfikacja obejmuje następujące rodzaje banków: a) biletowe, b) depozytowe, c) hipoteczne, d) przemysłowe. Pierwszy z wymienionych posiada upoważnienie od władz do emitowania banknotów; jego wyjątkowe stanowisko wynika z możliwości zyskiwania w wyżej wskazany sposób środków obiegowych, za które nie płaci żadnych odsetek. W każdej chwili może też powiększać sumę środków obiegowych (emisja banknotów), w przeciwieństwie do innych banków, które są ograniczone do własnych zapasów gotówki, sald rachunków wkładowych, reeskontu weksli itd. Bank biletowy powinien czuwać, aby emisja biletów (banknotów) była dostosowana do potrzeb obiegu, co pozwala zapobiegać dewaluacji ${ }^{3}$.

Bank depozytowy jest zakładem finansowym, którego kapitał tworzą przede wszystkim depozyty. Można je podzielić na banki depozytowe, kasy oszczędności oraz towarzystwa kredytowe. Pierwsze z wymienionych zajmują się interesami depozytowymi (osiąganie zysków przez kupców). Ich działalność zasadza się na

${ }^{2}$ Szerzej zob. C. Kosikowski, M. Olszak, Od prawa bankowego do prawa rynku finansowego [w:] J. Głuchowski (red.), System Prawa Finansowego, t. IV: Prawo walutowe, dewizowe, rynku finansowego, Warszawa 2010, s. 195-196.

${ }^{3}$ F. Wiliński, op.cit., s. 26-27. Wśród jego pozostałych zadań można wskazać wpływanie na rozwój handlu i przemysłu (regulowanie życia ekonomicznego) poprzez eskont weksli i lombard; ustalanie stosunku waluty krajowej względem zagranicznej (poprzez skupowanie złota, srebra i dewiz); usuwanie skutków braku gotówki na rynku (poprzez koncentrację obrotu żyrowego i kompensacyjnego); udzielanie pomocy finansowej rządowi. 
przyjmowaniu wkładek na rachunki bieżące, żyrowe i czekowe, a także lokowaniu kapitałów, zazwyczaj w eskoncie weksli, w lombardach lub kredytach kontokorentowych (czyli kontrolowanych). Stąd inna nazwa tego rodzaju instytucji to bank dyskontowy lub lombardowy. Banki hipoteczne (ziemskie) są instytucjami kredytowymi udzielającymi pożyczek hipotecznych, poprzez emisję listów zastawnych; ich podstawowym celem jest udzielanie kredytu długoterminowego dla właścicieli gospodarstw rolnych. Jest on zapewniany w drodze emisji biletów zastawnych. Banki przemysłowe współpracują przy zakładaniu i przekształcaniu przedsiębiorstw przemysłowych, a także emisji papierów wartościowych. Ich podstawowym zadaniem jest przyczynianie się do wzrostu uprzemysłowienia kraju ${ }^{4}$.

Uprawnione jest stwierdzenie, że szczególnie dynamiczny rozwój banków miał miejsce w pierwszej połowie XIX w. W ich organizacji wiodącą rolę odgrywali monarchowie. Jeszcze u schyłku XVIII w. (1782 r.) powstał hiszpański „Banco Nacional de San Carlos”. Przybrał on postać spółki akcyjnej. Bank miał ułatwiać rozwój handlu (m.in. przez udzielanie pożyczek i dyskontowanie weksli), wspierać działalność gospodarczą oraz przyczyniać się do zwalczania lichwy. Przy tym wszystkim, kluczowe było pozyskiwanie środków finansowych na potrzeby państwa. W 1800 r. z inicjatywy Napoleona I Bonaparte powstał Bank Francji. Jego zadaniem było przywrócenie ładu pieniężnego i wspieranie rozwoju gospodarczego państwa. W początkach działalności bank zajmował się emisją banknotów - w Paryżu i regionie paryskim - przy czym utrzymano konkurencję banków w dziedzinie emisji. W 1803 r. zadekretowano wyłączność emisyjną Banku Francji w stolicy, którą w kolejnych latach rozciągnięto na dalsze obszary kraju. Bank Narodowy Holandii (DNB) utworzono w 1814 r. Również jego celem było wspieranie rozwoju gospodarczego, a to dzięki stworzeniu nowych możliwości kredytowych oraz pobudzaniu inicjatywy prywatnych przedsiębiorców. W Holandii wprowadzono monopol emisyjny, zagwarantowano też wymienialność nowych banknotów na złoto lub srebro. Bank wykonywał funkcje kasjera Królestwa Holandii. W 1816 r. również cesarstwo austriackie doczekało się swojego banku centralnego. Głównym zadaniem „Privilegirte Oesterreichische National-Banku" było ustabilizowanie systemu monetarnego, zrujnowanego wskutek wojen napoleońskich. Cesarz Franciszek I nadał bankowi uprawnienia do wyłącznej emisji banknotów5

${ }^{4}$ Banki przemysłowe zwane są również bankami emisyjnymi, ponieważ większość ich operacji polega na emitowaniu papierów wartościowych przedsiębiorstw przemysłowych przez nie finansowanych, a także emisji publicznych papierów kredytowych. Najpełniej ujawniają swoje znaczenie w krajach słabo uprzemysłowionych. Zajmują się m.in. zakładaniem przedsiębiorstw, przekształcaniem już istniejących w spółki akcyjne, a także udzielaniem kredytu obrotowego dla przemysłu. Ich działalność jest obarczona dużym ryzykiem. Szerzej zob. F. Wiliński, op.cit., s. 27-32.

${ }^{5}$ Szerzej zob. W. Baka, Bankowość centralna: funkcje - metody - organizacja, Warszawa 1998, s. 15-16, 167-168, 189-190, 203-204, 217-218. 
Najstarszą instytucją emisyjną na ziemiach polskich była, utworzona w okresie powstania kościuszkowskiego (1794 r.), Dyrekcja Biletów Skarbowych; od 1810 r. w Księstwie Warszawskim funkcjonowała Główna Kasa Wymiany ${ }^{6}$. W 1825 r. w Królestwie Polskim powstało Towarzystwo Kredytowe Ziemskie, mające za zadanie ułatwianie rozwoju kredytu hipotecznego dla rolnictwa. W 1828 r. utworzono w Warszawie Bank Polski. Był on instytucją państwową, łączącą funkcje emisyjne $\mathrm{z}$ zadaniem organizacji kapitałów na potrzeby industrializacji. W latach trzydziestych i czterdziestych XIX w. bank zaangażował się m.in. w finansowanie rozwoju okręgu staropolskiego. Po likwidacji odrębności walutowej Królestwa Polskiego (1841 r.) funkcje emisyjne banku uległy ograniczeniu, aczkolwiek spełniał je on, w ograniczonym zakresie, aż do 1870 r. ${ }^{7}$. Warto wspomnieć, że w Warszawie pierwszej połowy XIX w. działało też kilkanaście prywatnych domów bankowych, m.in. Samuela Fraenkla, Aleksandra Wertheima oraz Samuela Kronenberga. W tym samym czasie, w zaborze austriackim prowadziło działalność kilkadziesiąt niewielkich domów bankowych. W 1841 r. we Lwowie utworzono Galicyjski Stanowy Instytut Kredytowy, który zajmował się głównie kredytowaniem rolnictwa ${ }^{8}$.

\section{PROJEKT BANKU KRAJOWEGO AUTORSTWA HILAREGO MECISZEWSKIEGO}

W tym czasie swojego banku nie posiadało Wolne Miasto Kraków. O potrzebie jego powołania zaczęto mówić na początku lat trzydziestych XIX w., kiedy to z inicjatywą na forum Zgromadzenia Reprezentantów wystąpił Hilary Meciszewski; był to polityk nastawiony opozycyjnie wobec rezydentów „Trzech Mocarstw Opiekuńczych", dość ostentacyjnie ingerujących w podstawy autonomicznego bytu Rzeczypospolitej Krakowskiej ${ }^{9}$. Zresztą, obradujący od 22 VIII do 18 IX

${ }^{6}$ Szerzej zob. W. Morawski, Stownik historyczny bankowości polskiej do 1939 roku, Warszawa 1998, s. 23-27.

${ }^{7}$ Bank Polski posiada bogatą literaturę naukową. Zob. L. Gluck, Bank Polski 1828-1885. Fakty i problemy [w:] Bank Polski 1828-1885. Dla upamiętnienia 160 rocznicy otwarcia Banku Polskiego, Warszawa 1988; A. Grodek, Idea Banku Narodowego (Geneza Banku Polskiego 1763-1828) [w:] idem, Studia z historii myśli ekonomicznej, Warszawa 1963, s. 252-258, 291-307. Ogólnie: Z. Stankiewicz, Królestwo Polskie (1815-1863) [w:] J. Bardach i M. Senkowska-Gluck (red.), Historia państwa i prawa Polski, t. III: Od rozbiorów do uwłaszczenia, Warszawa 1981, s. 385-387; A. Jezierski, C. Leszczyńska, Historia gospodarcza Polski, Warszawa 2001, s. 132-133; I. Kostrowicka, Z. Landau, J. Tomaszewski, Historia gospodarcza Polski XIX i XX wieku, Warszawa 1984, s. 119-120.

${ }^{8}$ W. Morawski, op.cit., s. 10-12; idem, Bankowość prywatna w II Rzeczypospolitej, Warszawa 1996, s. 13-15. Banki akcyjne pojawiły się w Galicji dopiero w latach 60. XIX w. (podobnie w zaborze pruskim).

${ }^{9}$ H. Meciszewski (1803-1855) był z zawodu publicystą i reżyserem teatralnym. Jego biogram: Z. Jabłoński, Meciszewski Hilary, „Polski Słownik Biograficzny”, t. XX, Wrocław - War- 
1833 r. sejm stał się areną ostrej walki politycznej między opozycją antysenacką a zwolennikami ugodowego kursu wobec państw ościennych ${ }^{10}$.

Z kronikarskiego obowiązku należy odnotować, że w krakowskim parlamencie zasiedli wówczas delegaci Senatu (Jacek Mieroszewski, Józef Haller), krakowskiej kapituły katedralnej (ks. Mikołaj Janowski, ks. Antoni Rozwadowski) oraz Uniwersytetu Jagiellońskiego (profesorowie Feliks Słotwiński i Ferdynand Kojsiewicz $)^{11}$. Na marszałka sejmu obrano Mieroszewskiego ${ }^{12}$. Merytoryczna ocena wniosków należała do komisji sejmowych: prawodawczej i skarbowej ${ }^{13}$.

Po raz pierwszy o zamysłach utworzenia Banku Krajowego posłowie dowiedzieli się 28 VIII 1833 r. Tego dnia Meciszewski zapowiedział wniesienie świeżo napisanego projektu, którego materię podzielił między cztery tytuły i kilkanaście rozdziałów ${ }^{14}$. Równolegle na forum parlamentu pojawił się konkurencyjny projekt J. Hallera ${ }^{15}$. Zgodnie z obowiązującą procedurą, 12 IX 1833 r. marszałek

szawa - Kraków - Gdańsk 1975, s. 359-362. O działalności politycznej na forum parlamentu zob. J. Bieniarzówna, Z dziejów liberalnego i konspiracyjnego Krakowa (1833-1846), „Biblioteka Krakowska" nr 106, Kraków 1948, s. 31-34, 36-46.

${ }^{10}$ Przedmiotem sporu było utrzymanie Katedry Literatury Polskiej na Uniwersytecie Jagiellońskim, przestrzeganie regulaminu sejmowego, a także dopuszczenia publiczności (,arbitrów”) na salę obrad sejmowych. J. Bieniarzówna, J.M. Małecki, Dzieje Krakowa, t. 3: Kraków w latach 1796-1918, Kraków 1979, s. 89; Rzeczpospolita Krakowska. Wybór źródet, wstępem i objaśnieniami opatrzyła J. Bieniarzówna, Wrocław 1951, s. 345.

${ }^{11}$ Nadto przedstawiciele gmin miejskich (Jakub Czerniński, Jan Kanty Piechocki, Marceli Bugajski, Hilary Meciszewski, Adam Czapski, Jan Giełg, Franciszek Lipczyński), wiejskich (Leon Rudowski, Józef Zapalski, Tomasz Bader, Aleksander Kiełczewski, Józef Raciborski, Erazm Skrzyński, Kasper Bielecki, Kajetan Florkiewicz, Józef Szembek, Konrad Złowodzki, Józef Krasuski, Grzegorz Ligięziński, Kasper Waligórski) oraz sędziowie pokoju (Wojciech Like, Jan Librowski, Tadeusz Konopka, Franciszek Łącki). Lista Reprezentantów na Zgromadzenie w miesiącu sierpniu 1833 roku, „Akta Seymu Wolnego Miasta Krakowa i Jego Okręgu z roku 1833-go”, Archiwum Narodowe w Krakowie (dalej: ANK), sygn. WMK II-40, k. 57-58; Dyaryusz Seymu Rzeczypospolitey Krakowskiey roku 1833, ANK, WMK II-39, k. 5-6; „Gazeta Krakowska” nr 219 z 21 VIII 1833.

12 Posiedzenie 1 (21 VIII 1833), „Diariusz Seymu Rzeczypospolitey Krakowskiey”, dodatek do „Dziennika Praw WMK”. Asesorami sejmowymi zostali J. Szembek i J.K. Piechocki, sekretarzem F. Kojsiewicz.

${ }^{13}$ Posiedzenie 2 (22 VIII 1833), ibidem. W Komisji Sejmowo-Prawodawczej zasiedli Kojsiewicz, Słotwiński, Like i Piechocki, w Sejmowo-Skarbowej Lipczyński, Librowski, Rudowski i Konopka.

${ }_{14}$ Posiedzenie 5 (28 VIII 1833), „Diariusz Seymu Rzeczypospolitey Krakowskiey” z 1833 roku; Dyaryusz Seymu Rzeczypospolitey Krakowskiey roku 1833, WMK II-39, k. 54. Projekt miał być uzupełnieniem ustawy o Towarzystwie Emerytalnym, nad którą pracował wówczas sejm.

15 J. Haller (1783-1850) pochodził z zamożnej rodziny kupieckiej, był absolwentem Wydziału Prawa UJ. Biogram: S. Pełeszowa, Haller Józef, Polski Słownik Biograficzny, t. IX/2, z. 41, Wrocław-Kraków-Warszawa 1961, s. 252-253. Najważniejsze wydarzenia z jego biografii: 1816 członek loży wolnomularskiej „Przesąd Zwyciężony”; 1822 poseł do Zgromadzenia Reprezentantów; 1829 członek honorowy Krakowskiego Towarzystwa Naukowego; 1833 senator; 26 II 1836-27 IV 1839 prezes Senatu. Działalność publiczna Hallera była przez współczesnych oceniana krytycznie. Zob. W. Kopff, Wspomnienia z ostatnich lat Rzeczypospolitej Krakowskiej, „Biblioteka Krakowska” 
sejmu przesłał oba projekty Senatowi ${ }^{16}$. Zobowiązano przy tym rząd do uzyskania zgody Komisji Reorganizacyjnej na wprowadzenie przepisów, które mogły skutkować nadmiernym obciążeniem finansowym państwa ${ }^{17}$.

Przechodząc do omówienia założeń obu projektów, należy stwierdzić, że dla Meciszewskiego utworzenie banku miało przede wszystkim zwiększyć dostępność kredytu publicznego, który w ówczesnych warunkach był bardzo drogi, „upadając pod ciężarem wysokiej stopy procentu”. Skutkować to miało rozwojem przemysłu, handlu i rzemiosła. Bank miał też stanowić remedium na permanentne problemy finansowe państwa: za jego pośrednictwem Skarb Publiczny mógł przejąc dochody, które dotąd przypadały uprzywilejowanej grupie przedsiębiorców („osób szczególnych”), dobrze zarabiających na handlu tranzytowym oraz „przedsięwzięciach kopalnianych i defluidacyjnych” (żeglugowych, dotyczących spławu towarów). Bank miał też dostarczać środków finansowych niezbędnych dla rozwoju infrastruktury (budowa dróg, mostów, kanałów itp.) ${ }^{18}$.

W tytule I projektu Meciszewski zaproponował dla planowanej instytucji nazwę: „Bank Wolnego Miasta Krakowa”. Należy dodać, że autor dobrze orientował się w ówczesnej terminologii finansowo-bankowej: nie był mu obcy podział banków na prywatne i państwowe ${ }^{19}$, a także dalsze ich klasyfikacje ${ }^{20}$.

W zamierzeniach Meciszewskiego bank miał się przyczynić do wzrostu obrotów handlowych oraz stabilizacji kredytu publicznego, a oprócz tego ożywczo

nr 31, Kraków 1906, s. 24-25; K. Girtler, Opowiadania, t. 1: Pamiętniki z lat 1803-1831, oprac. Z. Jabłoński, Kraków 1971, s. 270-272; S. i S. Mieroszewscy, Wspomnienia z lat ubiegłych, oprac. M. i H. Baryczowie, Kraków 1969, s. 205.

16 Pisma Prezydującego w Zgromadzeniu Reprezentantów do Senatu Rządz. z 12 IX 1833 nr 153, ANK, WMK V-202, k. 393 oraz z 13 IX 1833 nr 167, ibidem, k. 383.

17 Pismo Prezydującego w Zgromadzeniu Reprezentantów do Senatu Rządz. z 12 IX 1833 nr 153, WMK V-202, k. 393. W projekcie Meciszewskiego były to artykuły o finansowaniu działalności banku oraz wypuszczeniu w obieg biletów bankowych (art. 2, 3, 8, 13, 65).

${ }_{18}$ H. Meciszewski, Projekt do ustanowienia Banku Wolnego Miasta Krakowa, do laski Prezydującego w Zgromadzeniu Reprezentantów 1833 roku przez reprezentanta Hilarego Meciszewskiego złożony, Kraków 1833 (to samo w: WMK V-202, k. 395-406). Stopa procentowa dochodziła do 30-40 \%. J. Bieniarzówna, J.M. Małecki, Dzieje Krakowa..., s. 117.

19 Szerzej zob. H. Meciszewski, O potrzebie i użyteczności zaprowadzenia Banku Publicznego Rządowego w Wolnym Mieście Krakowie z Okręgiem. Przymówienie się Hilarego Meciszewskiego, członka Komitetu Bankowego, z grona Izby Reprezentacyjnej do rozpoznania projektu o Banku delegowanego, na posiedzeniu tegoż Komitetu $w$ dniu 15 grudnia 1834 r. odczytane, wraz z annexem aktu sejmowego do Nr 242 z 1833 r. obejmujacym: Projekt do zaprowadzenia Banku prywatnego z Akcyonariuszów, przez JW. Haller delegowanego z Senatu do Izby na dniu 15 września 1833 r. wniesiony; Uwagi reprezentanta Meciszewskiego nad tymże projektem; Decyzja Senatu Rządzacego z 16 września 1833 r. do L. 5967 w tey mierze zapadta; na koniec Uwagi JW Haller delegowanego z Senatu, nad tymże projektem przy ogłoszeniu go drukiem poczynione, Kraków 1835, s. 20-32.

${ }^{20}$ Wyróżniał banki: a) depozytowe (składowe); b) żyrowe (przekazowe); c) asygnacyjne (cyrkulacyjne); d) wekslowe (dyskontowe); e) kredytowe (pożyczające kapitały). Szerzej zob. H. Meciszewski, op.cit., s. 17-20. 
wpłynąć na przemysł krajowy, zapewniając tym samym fiskusowi dalsze korzyści ze „szczególnych przedsięwzięć handlowych”21. W kwestiach organizacyjnych Meciszewski proponował, aby w skład zarządu banku wchodzili prezes i wiceprezes, 2 dyrektorów, 2 radców handlowych, a także 3 członków Nieustającej Komisji Obrachunkowej22. Stanowiska prezesów, mianowanych przez sejm spośród kandydatów legitymujących się kwalifikacjami określonymi dla senatorów, miały być dożywotnie ${ }^{23}$. Dyrektorzy mieli być powoływani przez Senat. Od kandydatów wymagano znajomości języków obcych, zasad buchalterii kupieckiej, a także „biegłości w rachunkach”. Radców bankowych miała zaś wskazywać Kongregacja Kupiecka na okres jednego roku; posady radców były bezpłatne; Meciszewski przewidywał uchwalenie osobnego „Urządzenia dla służby bankowej”"24.

Bank Krajowy miały tworzyć cztery wydziały: I. Handlowy i Przemysłu, II. Zmiany i kupna papierów publicznych, III. Kredytowy, IV. Umorzenia długu krajowego. Na czele wydziałów I-III mieli stać wiceprezes bądź dyrektorzy; kierowanie wydziałem IV zarezerwowano dla prezesa Banku. W posiedzeniach plenarnych wydziału II obowiązkowo mieli uczestniczyć, z głosem doradczym, dwaj radcy handlowi; w pracach wydziału IV - również członkowie Komisji Sejmowo-Skarbowej. Najważniejsze decyzje miały zapadać kolegialnie, w przypadku „plenum” z zachowaniem kworum 5-osobowego (dla wydziałów: 3-osobowego). Bank pozostawałby pod naczelnym nadzorem Prezesa Senatu Rządzącego, któremu szefostwo banku miało składać raporty z bieżącej działalności. Zarząd banku miał się stosować do wszelkich jego poleceń, wydanych w oparciu o uchwały rządowe ${ }^{25}$.

Główną bolączką autorów projektów było znalezienie źródeł finansowania działalności banku. W projekcie Meciszewskiego rozwiązano to w ten sposób,

${ }^{21}$ H. Meciszewski, Projekt do ustanowienia Banku..., Tytuł I „Ustanowienie Banku. Skład jego in pleno i Wydziały”. Rozdział I „Ustanowienie Banku i skład jego” (art. 1).

${ }^{22}$ Nieustającą Komisję Obrachunkową powołano dla „kontrolowania i porządkowania rachunkowości wszelkich gałęzi administracyjnych, stosownie do prawideł postanowionych”. Pracowała między obradami sejmu, który wybierał ją na 3-letnią kadencję. Zob. art. XIV Konstytucji WMK i jego Okręgu z 29 lipca 1833 roku [w:] M. Kallas, M. Krzymkowski, Historia ustroju i prawa w Polsce 1772/1795-1918. Wybór źródel, Warszawa 2006, s. 196. O Komisji więcej: P.M. Pilarczyk, Nieustająca Komisja Obrachunkowa. O kontroli państwowej w Rzeczypospolitej Krakowskiej, „Czasopismo Prawno-Historyczne” 2012, t. LXIV, z. 2.

${ }^{23}$ Były to wymogi: a) przynależność do jednego z wyznań chrześcijańskich, b) ukończone 35 lat, c) wykształcenie wyższe, uzyskane w Krakowie bądź w „,państwach trzech opiekuńczych dworów”, d) posiadanie nieruchomości miejskiej bądź wiejskiej, z których opłacano podatek gruntowy. Zob. Konstytucja WMK i jego Okręgu z 29 lipca 1833 roku..., s. 199-200 (art. XXI).

${ }^{24}$ H. Meciszewski, Projekt do ustanowienia Banku..., Tytuł I „Ustanowienie Banku. Skład jego in pleno i Wydziały”. Rozdział I „Ustanowienie Banku i skład jego” (art. 2-6). W urządzeniu miano określić liczbę i kompetencje ajentów, sekretarzy, adiunktów oraz służby buchalteryjnej.

${ }^{25}$ Ibidem (art. 7-12). Szczegółowy podział kompetencji między zarząd banku, wydziały oraz Senat, miano określić w „Statucie wewnętrznego urządzenia Banku Krajowego”. 
że ,początkowe uposażenie” banku miała stanowić kwota 2000000 złp. Kapitał miał zostać zebrany (,wypuszczony w obieg”) w drodze nieoprocentowanej („bezprocentowej”) pożyczki publicznej, przy pomocy emisji papierów bankowych $^{26}$. W jednej ze swych kolejnych publikacji Meciszewski doprecyzował, że miała ona zostać umorzona, w drodze czynności banku, poprzez przelanie funduszu amortyzacyjnego do kasy banku. Dokładniej, przy powrocie biletów bankowych z obiegu bank pobierałby $2 \%$ dyskonto, po czym miało nastąpić przelanie kwot z poszczególnych kas do Kasy Umorzenia; Meciszewski zakładał, że w ten sposób uda się corocznie uzyskać ok. 25000 złp. Amortyzacja miała się dokonać w ciągu 20 lat. Faktyczne oprocentowanie kredytu miało wynosić ok. $6 \%$ (oprocentowanie podstawowe na poziomie , 4 od sta" $+2 \%$ pobierane przez bank przy wymianie), co było rozwiązaniem korzystnym, jeżeli zestawić je z faktycznym, co najmniej 12\% oprocentowaniem kredytu w WMK (uzyskiwanym za pośrednictwem lichwiarzy). Koszty powyższej operacji określał Meciszewski jako niewielkie, również w porównaniu ze stratami wywołanymi nieobecnością banku w życiu gospodarczym kraju. Zwracał też uwagę, że „,oprocentowanie przy wymianie" skutecznie zapobiegnie masowej wymianie biletów bankowych na monetę brzęczącą, co mogło jedynie przysporzyć bankowi trudności w akcji kredytowej (z powodu braku środków w kasie) ${ }^{27}$.

Meciszewski przekonywał też, że w sąsiednich państwach wprowadzenie do obiegu papierów wartościowych istotnie przyczyniło się do ożywienia handlu oraz wzrostu gospodarczego ${ }^{28}$. Jego zamierzenia były ambitne. Meciszewski planował wprowadzenie do obiegu trzech rodzajów (tzw. klas) biletów bankowych (banknotów): 500000 szt. biletów 1-złotowych (I klasy), 200000 szt. 5-złotowych (II klasy; łączna wartość $1 \mathrm{mln}$ złp) oraz 50000 szt. 10-złotowych (III klasy), o łącznej wartości 500000 złp. Bilety bankowe miały „służyć właścicielom”, za których uważano osoby okazujące bilet. Ponieważ nie miały przynosić prowizji, dozwolona była jedynie ich wymiana na inne środki płatnicze, za pośrednictwem kas rządowych. W razie wymiany na „monetę brzęczącą” miano potrącać po

${ }^{26}$ Ibidem, Tytuł II „Uposażenie Banku” (art. 16). Rozpisanie powszechnej pożyczki, przez Senat we współpracy z Wydziałem IV, mogło się odbyć wyłącznie na podstawie ustawy.

${ }^{27}$ Sposób ten Meciszewski określał jako „uposażenie banku na drodze antycypacji, wraz z późniejszym umorzeniem". H. Meciszewski, O potrzebie i sposobach uposażenia Banku Publicznego..., s. 26-31. Meciszewski zakładał, że podobnie jak w Królestwie Polskim, wraz ze wzrostem zaufania do instytucji kredytowej, dojdzie do obniżenia poziomu wymiany biletów bankowych na gotówkę (,monetę brzęczącą”). Zob. W. Morawski, Słownik historyczny..., s. 26-27.

${ }^{28}$ H. Meciszewski, Projekt do Prawa upoważniajacego Senat Rzadzacy wraz z Kommisja na ten cel wyznaczona, do wybicia Papierów Bankowych w wartości 2000000 ztp, do laski Prezydującego w Zgromadzeniu Reprezentantów 1833 roku przez reprezentanta Hilarego Meciszewskiego złożony, Kraków 1833 (to samo w: WMK V-202, k. 387-391). Emisja podlegała tam wszakże „kontroli narodowej”. 
3 gr. od każdych 5 złp, uzyskane środki przeznaczać zaś na „fundusz umorzenia biletów bankowych". Projekt wprowadzał też limity wymiany na gotówkę, obejmującej jedynie bilety powyżej 5 złp (była to minimalna wartość wymiany). Na żądanie, kasa banku dokonywała wymiany biletów 10-złotowych na 5-złotowe, tych zaś na 1 -złotowe ${ }^{29}$.

Emisja papierów bankowych miała się odbywać pod nadzorem specjalnej komisji finansowej, w której skład wchodziliby: a) członkowie Komisji Obrachunkowej, wyłonionej przez sejm na podstawie art. XIV Konstytucji; b) trzej senatorowie; c) wyznaczony przez Senat kontroler rachunkowości. Kworum miały tworzyć trzy osoby, udział kontrolera był obowiązkowy. Przygotowanie wzorów biletów bankowych oraz ich wydrukowanie („,bicie biletów”) zamierzano powierzyć „osobom przysięgłym”. Po wykonaniu dzieła, narzędzia i wzory miały zostać komisyjnie zniszczone. Wydrukowane bilety bankowe miano zdeponować w Kasie Głównej WMK, a następnie złożyć do opieczętowanych ksiąg. Przed rozpoczęciem działalności przez bank komisja miała przygotować bilety do wypuszczenia w obieg. Każdy bilet należało opatrzyć osobnym numerem porządkowym, który wycinano z księgi, arkusz po arkuszu, zastrzegając, aby jego „grzbiet pozostał w księdze”. Przygotowane w ten sposób bilety bankowe miano przesłać do kasy banku, na zasadach art. 13 projektu. Grzbiety miano pozostawić w Kasie Umorzeń, w celach dowodowych (z art. 24 projektu) ${ }^{30}$.

W projekcie z 1833 r. wśród źródeł finansowania banku Meciszewski wskazywał także dotację budżetową (,,remanent Skarbu Publicznego z ostatniego roku etatowego"), którą w następnym roku obliczył na ok. 25000 złp. Istotne uzupełnienie miały stanowić kwoty przypadające WMK od rządu Królestwa Polskiego, z tytułu wierzytelności skarbowych (w tym przypadku wysokość dotacji byłaby uzależniona od skuteczności Senatu w dochodzeniu swych praw); oprócz tego, tzw. superaty Skarbu Publicznego, uzyskane czy to w drodze nadzwyczajnych oszczędności, czy to usprawnienia administracji dochodów krajowych; wreszcie, coroczne zyski banku z „czynności własnych i obrotów”. Po zgromadzeniu przez bank całkowitego kapitału zakładowego (5 mln złp), jego dalsze dochody (,superaty”) miały stanowić zysk Skarbu Publicznego („obrót na korzyść Skarbu

${ }^{29}$ Projekt do Prawa upoważniajacego Senat..., Tytuł II „Puszczenie w obieg i warunki jego” (art. 10-16). Wypłaty w kasie banku miały następować „w miarę posiadanych zapasów”, w gotówce bądź w papierach bankowych.

30 Projekt do Prawa upoważniającego Senat..., Tytuł I „Wygotowanie biletów” (art. 1-9). Najważniejsze czynności („główny kierunek”) związane z emisją biletów bankowych zastrzeżono dla Prezesa Senatu. Rząd miał określić formę biletów i ich „szczególne znaki”, osobno dla poszczególnych klas biletów (dla każdej przewidywano inny kolor papieru). 
Publicznego"). Zgromadzenie Reprezentantów mogło podwyższyć kapitał zakładowy, w razie „uznanej krajowej potrzeby lub korzyści”’”.

Warto omówić w tym miejscu pozostałe sposoby zapewniania bytu bankowi rządowemu, którym hołdował Meciszewski. Było nim więc także sięgnięcie do kapitałów będących własnością publiczną, np. sum laudamialnych ${ }^{32}$, co „pozwoliłoby na ich korzystne spożytkowanie". Ponieważ kwota z kapitałów laudamialnych (w 1835 r. aż 700000 złp) była znacznie większa aniżeli planowany zysk z pożyczki publicznej, posłużenie się nią pozwoliłoby nawet na rezygnację $\mathrm{z}$ oprocentowania wymiany biletów bankowych ${ }^{33}$.

Trzecim sposobem, „wbrew pozorom najprostszym”, była „ofiara ogólna mieszkańców Wolnego Miasta”. Pod tym pojęciem kryła się sprzedaż akcji banku, jednakże bez możliwości pobierania dywidendy; nabyte akcje miały przynosić jedynie „stały i oznaczony procent”; akcjonariusze mogli również liczyć na wypłatę kapitału „w drodze losowania, z dołączonymi procentami”. Meciszewski (już na forum Komitetu Bankowego) przygotował też swego rodzaju symulację. Przy określeniu kapitału zakładowego na $1 \mathrm{mln}$ złp, Meciszewski sugerował wyemitowanie 3320 akcji po 100 złp (o łącznej wartości 332 tys. złp), 6600 akcji po 50 złp (333 tys. złp) oraz 13400 akcji po 25 złp (335 tys. złp), razem 23380 akcji. Przy oprocentowaniu 6\% (dla banku) oraz 4\% (dla akcjonariuszy) losowanie akcji oraz wypłatę oprocentowania należałoby prowadzić przez 35 lat, przy czym dla każdego losowania była przewidziana premia 8 tys. złp; wypłata ,procentu od akcji" mogłaby nastąpić dopiero w chwili wylosowania akcji; ponieważ rozpoczęcie losowań Meciszewski ustalił po upływie 3 lat od otwarcia banku, wobec corocznego losowania 35 tys. złp, w ciągu zamierzonego okresu miano wypłacić akcjonariuszom: $1 \mathrm{mln}$ złp „na kapitał”, 766400 złp tytułem procentu oraz 297483 złp tytułem rocznych premii (8 tys. złp). Dzięki temu, 2,2 mln złp pozostałoby w banku jako jego kapitał. W ciągu 20 lat bank zgromadziłby i wypłacił 4263883 złp (zakładając oprocentowanie na poziomie 6\%); oprócz korzyści wynikłych z ożywienia gospodarczego, widoczne byłoby więc przysporzenie ponad

${ }^{31}$ H. Meciszewski, Projekt do ustanowienia Banku..., Tytuł II „Uposażenie Banku”(art. 16-22). Nadwyżkę budżetową (,remanent budżetowy”) miała przekazać bankowi Kasa Główna WMK, której Meciszewski wyznaczył też rolę pośrednika w przekazywaniu sum należnych od Królestwa Polskiego, wkrótce po ich odzyskaniu.

${ }^{32}$ Sumy laudamialne (procent laudamialny) pobierano przy odsprzedaży posiadłości włościańskich i erbpachtów, w wysokości 2\% sumy szacunkowej. Początkowo przeznaczano je na potrzeby „funduszu usamowolnionych włościan”. Szerzej zob. pismo Rady Administracyjnej do Komisarza Nadwornego z 25 X 1847 nr 5925, WMK V-119, k. 751-753.

${ }^{33}$ H. Meciszewski, O potrzebie i sposobach uposażenia Banku Publicznego..., s. 34-35. Meciszewski nie obawiał się w tym przypadku jakichkolwiek zarzutów, gdyż sumy laudamialne ,pozostawały w dyspozycji rządu". 
2,2 mln złp ${ }^{34}$. Jako załącznik do swych rozważań, Meciszewski dołączył szczegółowe „objaśnienie sposobu losowania” akcji podlegających umorzeniu ${ }^{35}$.

W ogólności należy odnotować, że w projekcie Meciszewskiego do najważniejszych czynności Banku Krajowego należało: a) przyjmowanie depozytów oraz sum dla przekazów bądź lokowanych na procent przez rząd, Instytuty lub osoby prywatne; b) obrót funduszami, które miały na celu „wzrost handlu, przemysłu krajowego i ustalenie kredytu publicznego"; c) umarzanie wypuszczonych w obieg biletów bankowych ${ }^{36}$.

Konieczne jest też wyjaśnienie, że umorzenie długu publicznego (umorzenie papierów bankowych) miało się dokonywać przez wykupywanie weksli rządowych, wypuszczonych w obieg pod postacią papierów bankowych. Na ten cel Meciszewski zamierzał przeznaczyć: a) 2\% środków uzyskanych przez Bank Krajowy przy okazji wymiany papierów bankowych na gotówkę; b) dodatek 25000 złp rocznie, zapisywany w kolejnych budżetach aż do całkowitego wykupienia papierów publicznych; obie pozycje stanowiły „stały funduszu umorzenia” ${ }^{37}$. Bezpieczeństwo biletów bankowych miało być zabezpieczone przez sejm, na majątku narodowym WMK, w tym zwłaszcza jego dochodach stałych ${ }^{38}$.

Kwestie związane z obsługą długu publicznego miały należeć do Wydziału IV Banku Krajowego. Katalog jego zadań wyglądał następująco: a) nadzór nad „realnym wpływem” do bankowej Kasy Głównej sum pieniężnych wyemitowanych (,wypuszczonych w kurs") w papierach bankowych; b) czuwanie nad wpływem do Kasy Głównej kwot przeznaczonych na umorzenie długu publicznego, a także sum uzyskanych z procentu amortyzacyjnego, wskutek zwrotu papierów bankowych do kas rządowych; c) obsługa funduszy (,załatwianie wszelkich czynności") przeznaczonych na umorzenie papierów bankowych; d) cokwartalne „prawdziwe umorzenia” poprzez publiczne spalenie papierów bankowych, wykupionych z obiegu za pośrednictwem kas banku. Wydział miał też dbać, aby wpłacone do kasy banku, a następnie umorzone papiery bankowe nie były ponownie wprowadzane do obiegu publicznego. Przedkładał też Prezesowi Senatu comiesięczne raporty na temat stanu kasy wydziałowej, załatwionych czynności,

${ }^{34}$ Ibidem, s. 35-37. Meciszewski ponadto zakładał, że krakowskie akcje na okaziciela będą stanowić przedmiot spekulacji giełdowych (podobnie jak np. akcje wiedeńskiego banku Rotchschilda).

${ }^{35}$ Skala wypłaty kapitatu 1000000 ztp, czyli umorzenia 23380 sztuk akcji na tęż sumę wystawionych, wraz z procentem po 4/100 w przeciagu 35 lat, właczając do każdego losowania praemia w wartości ogolnej 8000 ztp oraz Objaśnienie sposobu losowania, załączniki do: H. Meciszewski, O potrzebie i sposobach uposażenia Banku Publicznego...

${ }^{36}$ H. Meciszewski, Projekt do ustanowienia Banku..., Tytuł III „Czynności Banku” (art. 23).

${ }^{37}$ Ibidem, Tytuł III „Czynności Banku” (art. 23-24).

38 Projekt do Prawa upoważniającego Senat..., Tytuł III „Przepisy ogólne” (art. 27-29). Senat miał też wydać ,instrukcję operacji umorzenia”. 
sum usuniętych z obiegu (poprzez spalenie) itp. ${ }^{39} \mathrm{~W}$ powyższych czynnościach wydział posługiwał się głównie Kasą Umorzenia ${ }^{40}$.

Jeśli chodzi o przelew funduszów, to środki z tytułu funduszu 2-procentowego kasy rządowe miały przelewać comiesięcznie do Kasy Umorzenia, po wpłynięciu do nich „powracających z obiegu” biletów bankowych. „Drugi fundusz” (czyli zasiłek budżetowy) miał być przelewany do Kasy Umorzenia przez Kasę Główną WMK, w czterech ratach kwartalnych. Wypłata środków znajdujących się w Kasie Umorzenia miała się odbywać „w monecie srebrnej, kurs w Kraju mającej”. Mogła ona używać powierzonych jej funduszów „w charakterze strony”, pod warunkiem, że wszelkie korzyści uzyskane „ze zmiany i sprzedaży papierów publicznych" bądź nabycia weksli, po cokwartalnym obrachowaniu, będą obracane na wykup papierów bankowych WMK, na zasadach określonych w art. 13-1441.

Szczegółowe zasady udzielania pożyczek („wypożyczania kapitałów”) Bankowi Krajowemu przez strony (oraz stopę procentową) miał określić Senat (w drodze rozporządzenia), na wniosek władz banku. Meciszewski przewidywał, że w razie nieodebrania w ciągu 12 miesięcy procentu od złożonych oszczędności, które urosły do kwoty powyżej 200 złp, należało uznać, że zostały one ponownie „wypożyczone" bankowi, na procent składany; w przypadku niezgłoszenia się po procenty proste, miały one być, wraz z procentami składanymi, w dalszym ciągu pomnażane (,rachowane”), ale jedynie do momentu ,podwojenia pierwiastkowego kapitału". Wpłacone pieniądze, wraz z oprocentowaniem, bank musiał wypłacić na każdorazowe żądanie, „W monecie srebrnej brzęczącej”"42.

W związku z powyższym, bank miał posiadać „przyzwoitą ilość funduszów w monecie brzęczącej”, aby umożliwić stronom wymianę biletów bankowych. Mógł też nabywać zagraniczne papiery publiczne, w Wolnym Mieście oraz za granicą, a także nabywać weksle i je zbywać. Zasady udzielania pożyczek na papiery publiczne, płody rolne etc. miał określić Senat w porozumieniu z władzami banku. W drodze ustawy miano również określić zasady wspierania „przedsię-

${ }^{39}$ H. Meciszewski, Projekt do ustanowienia Banku..., Tytuł I, Rozdz. II „Wydział umorzenia długu krajowego" (art. 13-15). Meciszewski przewidywał też odrębne ustalenie etatu dla Banku Krajowego. Niezbędne było ponadto szczegółowe określenie, w drodze instrukcji, zasad obsługi klientów (,wykonywania czynności ze stronami”).

${ }^{40}$ Ibidem, Tytuł III „Czynności Banku”, Rozdz. I „Umorzenie papierów bankowych” (art. 25). Kasa Umorzenia pozostawała pod ,ścisłym nadzorem” Wydziału IV oraz władz banku.

${ }^{41}$ Ibidem, Tytuł III „Czynności Banku”. Rozdz. I „Umorzenie papierów bankowych” (art. 26-29, 32). O stopniowym umarzaniu biletów bankowych przez Kasę Umorzenia władze banku miały co kwartał ogłaszać w prasie („do publicznej podawać wiadomości”), z zaznaczeniem, „,ile biletów cofnięto z obiegu, wiele ich w nim pozostało”.

42 Ibidem, Tytuł III „Czynności Banku”. Rozdz. II „Depozyta do Banku składane i kapitały na procent lub do przekazów" (art. 41-45). Nieodebrane depozyty miały być przekazywane władzom, dla ,postąpienia według przepisów prawa”. 
wzięć handlowych, kredytowych i przemysłowych". Pod koniec miesiąca bank miał podawać do publicznej wiadomości wysokość stóp procentowych, a także agio od weksli i papierów publicznych nabywanych przez bank. Stopa procentowa nie mogła być wyższa niż obowiązująca w obrocie handlowym (,procent prawny handlowy" $)^{43}$.

Zgodnie z projektem, fundusze banku mogły zostać przeznaczone na: a) wymianę własnych biletów na monetę brzęczącą; b) nabywanie i zbywanie zagranicznych papierów publicznych; c) skupywanie weksli; d) pożyczki pod zastaw papierów publicznych, płodów rolnych, wyrobów przemysłowych i kosztowności; e) pożyczki dla „zakładów fabrycznych lub przemysłowych” w Wolnym Mieście; f) finansowanie przedsięwzięć mających na celu „,wzrost handlu, przemysłu krajowego i ustalenie kredytu"44.

Do Banku Krajowego miano też przekazywać sumy pieniężne (powyżej 100 złp), oddane wcześniej do depozytu sądowego bądź administracyjnego, jak też będące w kasach magistratur lub u niektórych urzędników (notariuszy, komorników, kuratorów). Podobnie rzecz się miała, niezależnie od kwoty, z nie zainwestowanymi funduszami duchownymi i instytutowymi, funduszami Towarzystwa Ogniowego, Towarzystwa Emerytalnego oraz innych stowarzyszeń publicznych, a także zapasami kas budowy kanałów i dróg ${ }^{45}$.

Kapitały i depozyty bankowe miały być zwolnione z podatków oraz innych ciężarów publicznych. Nie mogły być zajęte dla zaspokojenia pretensji osób prywatnych bądź instytucji publicznych. Wyjątek stanowił sam Bank Krajowy, który mógł zająć kapitały, depozyty i towary, „na satysfakcję swoich należytości”, korzystając z „przywileju pierwszeństwa"46.

W działalności banku miała obowiązywać tajemnica bankowa, polegająca zarówno na zakazie ujawniania danych osób ,składających w depozyt bądź do przekazów i tytułem pożyczki”, jak też wysokości wkładów. Ujawnienia powyższych danych nie mogły zażądać władze sądownicze oraz inne organy władzy pub-

${ }^{43}$ Ibidem, Tytuł III „Czynności Banku”. Rozdz. III „Obroty funduszów Banku” (art. 47-51). Jeszcze przed rozpoczęciem działalności bank miał dysponować kapitałem 200000 złp. celem zapewnienia bieżącej wymiany biletów bankowych. Stąd projekt przewidywał pomoc rządową, w postaci zasiłku na potrzeby „realizacji czynności bankowych”.

${ }^{44}$ Ibidem, Tytuł III „Czynności Banku”. Rozdz. III „Obroty funduszów Banku” (art. 46).

${ }^{45}$ Ibidem, Tytuł IV „Przepisy ogólne” (art. 52-53). Wymienione środki miano oddawać w depozyt, na potrzeby przekazów bądź oprocentować, przy czym chodziło o zapewnienie bankowi gotówki. Wszystkie kapitały korzystałyby z profitów zapewnionych wkładom osób prywatnych (art. 36, 40-42); dotykały ich również ograniczenia (art. 45).

${ }^{46}$ Ibidem, Tytuł IV, Przepisy ogólne” (art. 54-55). Zajęciu podlegały jednak kapitały: a) złożone przez urzędników na zabezpieczenie pretensji Skarbu Publicznego, z tytułu szkód wyrządzonych w majątku rządowym; b) złożone przez nich na rzecz osób trzecich; c) oddane w zastaw aktem urzędowym; d) które właściciel „sam oddał na satysfakcję wierzycieli”. 
licznej. Wyjątek dotyczył popełnienia przez klienta banku przestępstwa: organy śledcze mogły się domagać od władz banku wyjaśnień („objaśnień”), korzystając z pośrednictwa Senatu. Jeżeli na podstawie „,notoryjnych i ustronnych zawiadomień" sąd uzyskał wiedzę o złożeniu w banku kapitałów, przy wydawaniu decyzji o tymczasowym aresztowaniu (,wyrok przedstanowczy”) osoby „wnoszącej kapitał" do banku, mógł zażądać od tego ostatniego złożenia odpowiedniej deklaracji oraz wstrzymania wypłaty pieniędzy, do czasu zapadnięcia ostatecznego wyroku ${ }^{47}$.

Pracownicy banku byli zobowiązani do przestrzegania prawa. Odpowiedzialność urzędników, osobista i majątkowa, obejmowała następujące czyny: a) uleganie poleceniom kogokolwiek, wbrew ustawie; b) przeznaczenie pieniędzy, depozytów, towarów, papierów i kosztowności, a także funduszów Kasy Umorzenia i Kasy Depozytowej, na cele inne niż ustawowe („na przedmiot nie zakreślony prawem") oraz nie zapobieżenie takiemu przeznaczeniu; c) nie wykonywanie prawomocnych wyroków sądowych; d) nie wykonywanie przyjętych na siebie zobowiązań. Poza tym, za wszelkie decyzje wydane na podstawie obowiązujących przepisów, pracownicy banku nie mogli zostać pociągnięci do odpowiedzialności. Przed sądami bank miał obowiązkowo reprezentować obrońca sądowy ${ }^{48}$.

W działalności banku cudzoziemcy mieli być traktowani na równi z obywatelami Wolnego Miasta, „niezależnie od jego przyszłego położenia politycznego”. Sumy depozytowe po zmarłym obcokrajowcu przechodziły na spadkobierców, zgodnie z prawem spadkowym właściwym dla kraju pochodzenia spadkodawcy. Bank mógł prowadzić bezpośrednią korespondencję ze wszystkimi władzami WMK, za wyjątkiem sejmu, a także z władzami państw obcych. Należy dodać, że Senat, w porozumieniu z bankiem, miał określić zasady działalności ajentów, a także wysokość taksy dla nich oraz brokerów („brakarzy”) ${ }^{49}$.

Meciszewski dokładnie opisał też obowiązki sprawozdawcze banku. Raz do roku, na otwartym dla publiczności spotkaniu (,publicznym posiedzeniu”), władze banku miały przedstawić „zdanie sprawy z czynności”. Przewidywano jego wydrukowanie, a następnie odczytanie na forum sejmowym, przez jedne-

47 Ibidem, Tytuł IV „Przepisy ogólne” (art. 56-57).

48 Ibidem, Tytuł IV „Przepisy ogólne” (art. 63-65). W obliczu prawa bank nie posiadał żadnej „wyłącznej prerogatywy”. Prezes i wiceprezes banku (oraz członkowie Komisji Sejmowo-Skarbowej, zasiadający w wydziale IV) podlegali odpowiedzialności przed Sądem Najwyższym, na zasadach określonych $w$ art. XIX Konstytucji. Pozostali pracownicy odpowiadali przed sądami zwyczajnymi (powszechnymi).

49 Ibidem, Tytuł IV „Przepisy ogólne” (art. 58-62). Korespondencja banku z klientami, jak też podpisywane umowy, miały być zwolnione od opłaty stemplowej. W sprawach korespondencji pocztowej, dotyczącej np. przesyłania pieniędzy i depozytów, bank miał się stosować do przepisów obowiązujących administrację rządową. 
go z wydelegowanych senatorów (art. 104 „Statutu Urządzającego Zgromadzenia Polityczne"). Na wniosek zarządu banku, Senat miał określić siedzibę banku („lokal posiedzeń bankowych”), nadać jego „wewnętrzne urządzenie”, a także zatwierdzić wzory ksiąg oraz pozostałej dokumentacji rachunkowej. Bank zobowiązano też do zwrotu, w pierwszym roku, w którym osiągnie zysk („czyste korzyści”), środków ze Skarbu Publicznego otrzymanych na rozpoczęcie działalności. Co istotne, Zgromadzenie Reprezentantów miało zabezpieczyć, na majątku i dochodach skarbowych, zarówno płynność finansową banku (,stały wpływ na umorzenie, czyli wykupno, biletów bankowych, budżetem Kasie Umorzenia przekazanych”), jak też „wszelkie kapitały, depozyty i inne wartości”, powierzone bankowi bądź stanowiące jego własność; wszelkie modyfikacje w prawie bankowym mógł wprowadzać wyłącznie sejm ${ }^{50}$.

Bilety bankowe, w ujęciu Meciszewskiego, mogły też służyć do opłacania podatków stałych. Odbywałoby się to wedle ich wartości nominalnej, w upoważnionych kasach rządowych. Uiszczanie podatków odbywałoby się bez oprocentowania $\mathrm{z}$ art. 13 projektu; dozwolone było też wnoszenie w biletach innych podatków i opłat, dochodów niestałych, kar i opłat stemplowych oraz sądowych, a także zobowiązań wynikających z czynszów i umów, wszystkie jednak z pobraniem „procentu amortyzacyjnego”; pod koniec miesiąca kasy miały obliczyć „czysty stan” 2-procentowego „funduszu amortyzacyjnego”, już po wymianie biletów na „monetę brzęczącą”, a następnie przelać pieniądze do Kasy Umorzenia; pokwitowania wypłat przesyłano rządowi; wymienione na gotówkę bilety bankowe mogły być ponownie puszczane w obieg przez kasy ${ }^{51}$.

Za fałszowanie biletów bankowych groziła odpowiedzialność karna. Czyn ów miano traktować jako fałszerstwo monety i karać na zasadach Kodeksu karnego z 1803 r. („Franciszkana”). Umieszczone na biletach bankowych znaki wodne miały być „najpewniejszą rękojmią ich tożsamości”. Kasom zakazywano przyjmowania biletów ,ze znakami zakrytymi przez podklejanie”, a także „wynagradzanie” (,rekompensowanie”) biletów zgubionych bądź zniszczonych. Mogły

${ }^{50}$ Ibidem, Tytuł IV „Przepisy ogólne” (art. 66-70). Projekt zastrzegał, że fundusze i wartości banku są nietykalne; niedozwolona była też zmiana ich przeznaczenia. Wykonanie ustawy powierzono Senatowi, który miał ją ogłosić w „Dzienniku Praw WMK”.

${ }^{51}$ Projekt do Prawa upoważniajacego Senat..., Tytuł II „Puszczenie w obieg i warunki jego” (art. 17-26). Za każde 100 złp przyjęte w biletach miano pobierać 102 złp, za każde 1000 złp 1020 złp itd. Kasy miały prowadzić księgi sznurowe, do odnotowywania wpływów w biletach bankowych; kwity z ksiąg wydawano by kontrybuentom (podatnikom), z podaniem uiszczonej kwoty oraz gatunku biletu. Zasady wypłaty sum należnych kasom określono w art. 25-26. Obowiązywać miał też księgi do wpisywania ,czystego procentu”. Rewizja ksiąg kasowych (przez właściwy wydział banku) miała się odbywać na zasadach ustalonych dla kontroli ksiąg skarbowych. 
uwzględnić jedynie „bilety poplamione i podarte”, gdyby możliwe było rozpoznanie „napisu, wartości, podpisów komisarzy, stempla i numeru porządkowego”. $\mathrm{W}$ takiej sytuacji dopuszczalna była ich wymiana na nowe bilety ${ }^{52}$.

\section{PROJEKT BANKU WMK AUTORSTWA JÓZEFA HALLERA}

Poddając analizie konkurencyjny projekt J. Hallera (wpłynął do sejmu 15 IX 1833 r.), należy odnotować identyczność nazwy („Bank Wolnego Miasta Krakowa"), a także tożsamość celów w stosunku do propozycji Meciszewskiego: głównym jego zadaniem miało być wspieranie rozwoju gospodarczego („ożywienie cyrkulacji wewnętrznej i przemysłu”). Mimo identyczności celów, bank z wyobrażeń Hallera zasadzał się na odmiennej koncepcji organizacyjnej oraz zasadach funkcjonowania. Przede wszystkim, bank miał stanowić własność akcjonariuszy, a nie państwa. Jego majątek tworzyłyby kapitały wniesione przez osoby prywatne, obywateli Rzeczypospolitej Krakowskiej oraz cudzoziemców („krajowców bądź obcych"), będących owymi akcjonariuszami. Bank miał rozpocząć działalność po zbyciu („rozebraniu”) pierwszych 500 akcji na okaziciela, każda o wartości 1000 złp. Z chwilą ogłoszenia ustawy kreującej bank, Senat miał podać do publicznej wiadomości informację o możliwości składania u komisarza delegowanego 1/10 kwoty, za którą przyszli akcjonariusze zamierzali nabyć akcje banku; pozostałą część mieli dopłacić po rozpoczęciu przez bank działalności. W razie nie wywiązania się z powyższego obowiązku i ,nie uzupełnienia części brakującej” w terminie miesięcznym, utraciliby prawo otrzymania akcji (,żądania wydania akcji”); wadium miano zwrócić w ciągu 1 roku, ale bez oprocentowania. Po zebraniu wymaganej kwoty $500000 \mathrm{złp}$, Senat miał wezwać akcjonariuszy na inauguracyjne posiedzenie ogólne celem ułożenia „statutu wewnętrznej administracji Banku”. Miano w nim określić rodzaje czynności bankowych, w granicach zakreślonych art. 11 projektu. Spośród akcjonariuszy miano wybrać Komitet Zarządzający i Dyrektorów Banku Krajowego. Członkami komitetu mogli zostać właściciele minimum 10 akcji, dyrektorami zaś osoby dysponujące 20 akcjami. Statut banku podlegał zatwierdzeniu przez Senat. Dla rządu Haller przewidywał następujący zakres praw i obowiązków: a) udzielanie gwarancji (,zaręczanie”), że bilety bankowe będą wymieniane, w każdej chwili, na znajdującą się w obiegu monetę srebrną, bez potrącenia prowizji; b) udzielanie upoważnień kasom publicznym do przyjmowania biletów bankowych według ich wartości nominalnej, zamiast mo-

${ }^{52}$ Projekt do Prawa upoważniajacego Senat..., Tytuł III „Przepisy ogólne” (art. 30-34). Senat mógł wyznaczyć nagrodę za wskazanie („odkrycie”) osób fałszujących monety. Wykonywanie ustawy, zgodnie z tradycyjną formułą pojawiającą się w ustawach sejmowych, miano powierzyć Senatowi. 
nety srebrnej, a także wypłacania należności w tych biletach. W związku z wprowadzeniem „rękojmi rządowej”, Bank Krajowy miał podlegać nadzorowi Senatu, za pośrednictwem komisarza rządowego. Do jego obowiązków należała dbałość, aby: a) bilety bankowe emitowano wyłącznie w ilości ustawowej; b) bank zajmował się wyłącznie czynnościami bankowymi; c) bank nie odnotowywał strat finansowych ${ }^{53}$.

Do najważniejszych czynności banku Haller zaliczał udzielanie pożyczek pod zastaw: a) metali, czyli złota i srebra, do 3/4 ich wartości; b) precjozów (drogie kamienie i perły), do $1 / 3$ wartości; c) nie podlegających zepsuciu towarów krajowych i zagranicznych, do $2 / 3$ wartości. Ponadto, należy wskazać skupywanie weksli od miejscowych kupców, uznanych za „,pewnych i wypłacalnych”, przez komitet wyznaczony spośród akcjonariuszy należących do Kongregacji Kupieckiej. Termin skupywania określono na 3 miesiące. Komisarz rządowy miał również dbać, aby „pożyczki na papiery publiczne”, do wysokości 2/3 wartości, były udzielane według kursu obowiązującego w danym dniu. Troszczył się również, aby Kasa Banku Krajowego była odpowiednio zaopatrzona w monetę srebrną, celem zapewnienia każdorazowej wymienialności biletów bankowych (wypłacalność). Bank miał rozpocząć emisję biletów bankowych po zgromadzeniu kapitału 500 tys. złp. Emisja miała osiągnąć wartość $1 \mathrm{mln}$ złp. W swoim projekcie Haller wprowadzał bilety bankowe o nominałach 10, 25, 50, $100 \mathrm{złp}$. W razie intensyfikacji czynności bankowych, za zgodą Senatu, bank mógł wyemitować dodatkowe akcje, w wyżej wskazanych proporcjach. Maksymalną stopę procentową Haller ustalił na $6 \%$. W uzasadnionych okolicznościach mogła ona zostać obniżona. Roszczenia (,pretensje”) banku wobec osób prywatnych mogły być dochodzone na drodze egzekucji administracyjnej. Fałszowanie biletów bankowych podlegało karom z Kodeksu karnego, stosowanym wobec fałszerzy papierów publicznych ${ }^{54}$.

\section{PRZEBIEG DYSKUSJI NAD PROJEKTAMI BANKU}

Należy odnotować, że Senat wyżej ocenił projekt Hallera, który miał stanowić punkt wyjścia dla dalszych prac nad prywatnym Towarzystwem Akcjonariuszów, mogącym przynieść „więcej korzyści osobom prywatnym”. W propozycjach Me-

53 J. Haller, Projekt do zaprowadzenia Banku Wolnego Miasta Krakowa, ANK, WMK II-40, k. 1813-1815 (art. 1-11); to samo jako załącznik do: H. Meciszewski, O potrzebie i użyteczności zaprowadzenia Banku Publicznego..., s. 33-37. Wprowadzono zastrzeżenie, iż obcokrajowcy muszą się wykazać zamieszkaniem w WMK. Senat mógł wyrazić zgodę na zwiększoną emisję jedynie w razie wystąpienia okoliczności z art. 13 projektu.

${ }^{54}$ J. Haller, Projekt do zaprowadzenia Banku Wolnego Miasta Krakowa, ANK, WMK II-40, k. 1815-1816 (art. 11-16). 
ciszewskiego Senatowi nie odpowiadało zwłaszcza niedostateczne określenie zasad poręczenia rządowego, w odniesieniu do „zamiany biletów bankowych na monetę srebrną"55.

Warto również odtworzyć przebieg gorącej polemiki między obu autorami, przy czym w pierwszym rzędzie ukazane zostaną krytyczne uwagi Hallera, w stosunku do koncepcji konkurenta. Oprócz zarzutu, że projekt Meciszewskiego został „naprędce skreślony”, Haller wysuwał tezę, że przy wyborze koncepcji organizacyjnej banku - tworzonego przez kapitały publiczne bądź ze środków prywatnych inwestorów - decydująca powinna być sytuacja finansowa Rzeczypospolitej Krakowskiej. Ta zaś była ewidentnie zła, co sprawiało, że nie było widoków powodzenia na zgromadzenie przez państwo funduszów potrzebnych do uruchomienia banku (chyba że znalazłyby się „dotąd nieodkryte środki”, na co Haller jednak nie liczył). Przestrzegał on również, że objęcie monopolem państwowym czynności handlowych i bankowych (a także innych czynności, związanych $\mathrm{z}$ funkcjonowaniem przedsiębiorstw), musi prowadzić do ogołocenia kraju ze środków pieniężnych. W opinii Hallera, bank państwowy ma rację bytu jedynie w krajach, których władcy inwestują pieniądze własne (jak w Królestwie Polskim) czy też stają się monopolistami (przykład Egiptu), „czyniąc to nie z żądzy zysku, lecz dla podniesienia gospodarczego państwa”. Dla Hallera realna była też groźba przekazywania bankowi środków budżetowych, które należałoby przeznaczyć na inne cele. W jego ocenie jedynym sensownym rozwiązaniem było utworzenie banku opartego o wkłady akcjonariuszy. Do korzyści płynących z takiego rozwiązania zaliczał on zwiększanie „massy obiegowej pieniądza” oraz łatwość podziału zysków między akcjonariuszy. Dostrzegał też, że zarządzanie przedsiębiorstwem przez prywatnych właścicieli jest efektywniejsze niż jego oddanie w ręce administracji państwowej, nie troszczącej się zbytnio o zyski. Na koniec Haller stwierdził, że fakt nie zgromadzenia przez prywatnych inwestorów odpowiednich środków byłby najlepszym świadectwem zbędności instytucji banku w społeczno-gospodarczych warunkach Wolnego Miasta. Jak również potwierdzeniem tezy o szczupłości pozostających do ich dyspozycji kapitałów. Haller zdecydowanie polemizował z tezą, że wszelkie kłopoty gospodarcze WMK wynikają z braku własnego banku ${ }^{56}$.

${ }^{55}$ Pismo Senatu Rządz. do Prezydującego w Zgromadzeniu Reprezentantów z 16 IX 1833 nr 5967, WMK V-202, k. 383 (to samo w: WMK II-40, k. 1811). W projekcie Meciszewski „nie wskazał stałej rękojmi, która mogłaby służyć rządowi za zakład pewności zaręczonych wypłat"; Por. H. Meciszewski, Uwagi nad projektem do ustanowienia w Wolnym Mieście Krakowie z Okręgiem Banku Publicznego Prywatnego z akcyonaryuszów złożonego..., s. 60.

${ }^{56}$ Uwagi Senatora Haller nad projektami zaprowadzenia Banku, nadestane przy ogloszeniu ich drukiem, załącznik do: H. Meciszewski, O potrzebie i użyteczności zaprowadzenia Banku..., 
13 września 1833 r. Meciszewski wystąpił z repliką wobec tez Hallera. Odpierał zarzut rzekomej niewykonalności projektu (,niepodobieństwa jego wykonania”). Przekonywał, że banki prywatne biorą pod uwagę jedynie „korzyści własne akcjonariuszów". Niechybnie stałoby się tak również w Wolnym Mieście, gdzie „,banki” działały „od dawna, bez żadnego na pomyślność krajową skutku, a może i ze szkodą onej" (chodziło o lichwiarskie pożyczanie pieniędzy przez wekslarzy). Wątpliwości Meciszewskiego budziło też udzielanie „rękojmi rządowej prywatnemu towarzystwu akcjonariuszów". Źródłem jego prawdziwego niepokoju była niemożność ustanowienia odpowiedniego nadzoru nad bankiem prywatnym. Nawet wymóg przyjmowania weksli w kasach rządowych nie mógł takich wątpliwości rozwiać, gdyż wówczas kontrola obejmowałaby czynności i wypłaty, które „,z natury samej handlowego zakładu prywatnych, jako kupieckiego, przed kontrolą wszelką zakryte by być musiały" ${ }^{57}$.

Meciszewski zbijał twierdzenia Hallera również w jednej z kolejnych broszur. W żadnym razie nie zarzucał mu nieczystych intencji; chciał raczej zachęcić swego adwersarza do „odstąpienia od myśli, w najszczerszej zapewne dla Kraju chęci powziętej”. Dostrzegał, że w życiu gospodarczym ma miejsce „nieustanna rywalizacja między interesem prywatnym a publicznym". Widoczna była również sprzeczność w dążeniach „,posiadaczy kapitałów, zainteresowanych w tym, aby stopa procentu jego użyczenia była jak największa” oraz „ogółu towarzystwa w Kraju tutejszym”, domagającego się ,jak najniższej stopy procentu, do ruchu i możebnych korzyści miejscowych zastosowanej”. Rozstrzygnięcie konfliktu interesów należało do legislatywy krajowej, niepożądana była wszakże sytuacja, w której „Rząd uprawnia i sankcjonuje prywatne korzyści, zmuszony do tego potrzebą lub co gorsza ulegając wpływowi prywatnego interesu”. Meciszewski był też przeciwnikiem „korporacji pieniężnej, uzbrojonej wyłącznym monopolem Rządu", jaką dostrzegał w parlamencie brytyjskim (pisał wręcz o dominacji parów i kupców, jako że spośród 638 deputowanych 387 zależało od ich nominacji). W jego ocenie Bank Amerykański „mniej się być zgubnym okazał”, aczkolwiek w czasie wojny roku 1812 „kapitaliści krajowi, pod płaszczem patriotyzmu”, skorzystali z kłopotów rządu. Meciszewski występował więc przeciwko oligarchii finansowej, która jest ,groźna, bo nie oparta na talentach i zdolnościach; udziałem jej członków jest nie spuścizna sławy i imion przodków, nie poświęcenie się dobru publicznemu, lecz trafiający do każdego przekonania środek, to jest pienią-

s. 39-40. Haller za naiwne uważał stwierdzenia, że „wszystko złe u nas z braku Banku pochodzi” i że „zaprowadzenie tegoż krainę naszą w jakieś Eldorado mlekiem i miodem płynące zamieni”.

57 Wniesienie Meciszewskiego do Izby Seymowey z 13 IX 1833, załącznik do: H. Meciszewski, O potrzebie i użyteczności zaprowadzenia Banku..., s. 37-38. Meciszewski twierdził, że wniesienie projektu Hallera pod obrady Zgromadzenia było niedopuszczalne, gdyż „banki prywatne” działały w Krakowie od wielu lat (propozycja nie dotyczyła więc nowego prawa). 
dze”. Wedle wiedzy Meciszewskiego owa oligarchia wywierała potężny wpływ na „wybory reprezentantów i pierwszych urzędników"

Dla Meciszewskiego zasadniczym celem banku powinno być obniżenie stopy procentowej. Odwoływał się on w tym miejscu do klasyków ekonomii: Adama Smitha, Davida Ricardo, Jean Baptiste Say'a oraz Fryderyka Skarbka ${ }^{59}$. Wynikało to $\mathrm{z}$ jego zainteresowania badaniami nad wpływem organizacji systemu bankowego na gospodarkę, należącymi do nauki ekonomii politycznej (,gospodarstwo krajowe"). Można uznać, że Meciszewski był wrogiem egoistycznie postępujących kapitalistów, którzy „więcej własnym jak pospolitym dobrem zajęci, nie zasługują na bezwzględne zaufanie, gdy widoki własne, pozorem dobra powszechnego pokrywają". Dodawał, że ich zyski są największe, gdy dwie pozostałe grupy społeczne, czyli właściciele ziemscy oraz „zatrudnieni przemysłem” są w niekorzystnej sytuacji finansowej, „potrzebując użyczenia kapitałów”. Meciszewski nie miał wątpliwości, że kapitaliści opierają się wszelkim działaniom mającym na celu zwiększenie obiegu pieniądza, z czego wynikały ich opory wobec utworzenia banku rządowego ${ }^{60}$.

W koncepcjach Hallera dostrzegał Meciszewski korzyści jedynie dla prywatnych akcjonariuszów; nie do przyjęcia było, aby mogli oni żądać poręczenia rządowego za własne wypłaty, a także przyjmowania asygnacji w kasach rządowych. Bank nie służyłby otwieraniu kredytu miejscowym kupcom, lecz jedynie wykonywaniu „czynności pewnych” (czyli nie obarczonych ryzykiem), za poręczeniem Kongregacji Kupieckiej; wszakże jednym z warunków prowadzenia działalności bankowej jest jego „pewność majątkowa”, wyrażająca się w zabezpieczeniu hipotecznym. Bank z wyobrażeń Hallera służyłby jedynie „ludziom majętnym i zamożnym", nie przyczyniając się w żaden sposób do podźwignięcia przemysłu i handlu; projekt wprowadzał też ,nieuzasadnione przywileje”, w tym brak podległości sądom krajowym, korzystanie z egzekucji administracyjnej, co nie było praktykowane „nawet pod najabsolutniejszymi rządami”. W opinii Meci-

${ }^{58}$ H. Meciszewski, Uwagi nad projektem do ustanowienia $w$ Wolnym Mieście Krakowie z Okręiem Banku Publicznego Prywatnego z akcyonaryuszów złożonego, wniesionym do Izby Reprezentacyjnej $w$ dniu 13 września 1833 r. ze strony delegowanego z Senatu senatora J. Hallera, przez H. Meciszewskiego C.K.B. z grona Izby Reprezentacyjnej do rozpoznania projektu Banku Publicznego Rządowego delegowanego poczynione, Kraków 1835, s. 3-7.

${ }_{59}$ Zob. L. Guzicki, S. Żurawicki, Historia polskiej myśli społeczno-ekonomicznej do roku 1914, Warszawa 1969, s. 99-111, 133-145; E. Lipiński, Historia polskiej myśli społeczno-ekonomicznej do końca XVIII wieku, WrocławWarszawa-Kraków-Gdańsk 1975, s. 435-436; W. Stankiewicz, Historia myśli ekonomicznej, wyd. 2, Warszawa 2000, s. 155-180, 310-315.

${ }^{60}$ H. Meciszewski, Uwagi nad projektem do ustanowienia w Wolnym Mieście Krakowie z Okręgiem Banku Publicznego Prywatnego z akcyonaryuszów złożonego..., s. 8-9, 15. Omówienie poglądów Meciszewskiego odnośnie teorii F. Skarbka, J. B Say’a, A. Smitha i D. Ricardo: ibidem, s. $13-14,16-17$. 
szewskiego, ustalenie stopy procentowej na $6 \%$, wprowadzenie nadzoru komisarzy rządowych, a także niespotykanego w innych regulacjach warunku poręczenia weksli miejscowych kupców i fabrykantów przez Kongregację Kupiecką, spowoduje niedostępność pożyczek dla drobniejszego handlu i fabrykantów; przewidziany w art. 3 wymóg sprzedaży 500 akcji dla rozpoczęcia działalności był niedopuszczalny, gdyż z łatwością mógł udaremnić ideę banku; powstanie banku nie mogło być „,uzależnione od dobrej woli” (jak przy „podpisach na bal składkowy lub ustanowienie resursy"), taka sytuacja nie występuje w prawodawstwie (wyjątkiem było Towarzystwo Ogniowe, ale jego aktywność nie była wielka; nie występowało też w Towarzystwie Kredytowym Ziemskim w Królestwie Polskim oraz w Towarzystwie Emerytalnym WMK); w opinii Meciszewskiego najlepsza dla zabezpieczania kredytu była forma rządu reprezentacyjnego, poręczenie rządowe wraz z możliwością przyjmowanie asygnat. Meciszewski zarzucał też Hallerowi niekonsekwencję: twierdził on, że z powodu braku nadwyżek budżetowych, bank Meciszewskiego ,pozbawiony jest wszelkiej materialnej i moralnej rękojmi" - jeżeli nawet było to prawdą, to jak Haller znajdował powyższe okoliczności przy tworzeniu banku prywatnego? Pytał więc Meciszewski: „niech udowodni, że nie mogąc ręczyć za samych siebie, jesteśmy zdolni być drugich ręczycielami?”. Poza tym Haller wykluczał poręczenie ze strony Zgromadzenia Reprezentantów w przypadku banku rządowego, ale dopuszczał w odniesieniu do prywatnego; Meciszewski twierdził, że udzielenie bankowi poręczenia przez sejm jest niedopuszczalne bez zapewnienia korzyści Skarbowi Publicznemu. W jego ocenie, nieuzasadnione było także wprowadzenie monopolu emisji (bicia) „asygnat upoważnionych wyłącznie do kursu w kasach rządowych”: powinno to przynosić Skarbowi odpowiedni dochód (na wzór monopolu solnego, 300 tys. złp rocznie), zaś brak opłaty na rzecz Skarbu Publicznego czynił realną groźbę „ściągnięcia całej gotowizny do kas banku, w razie wypuszczenia asygnat z kursem gwarantowanym przez Rząd". Do pomyślenia byłaby wówczas sytuacja celowego doprowadzenia Banku Krajowego do bankructwa, w kasach rządowych pozostałby wówczas ,prosty papier, który na koszt mieszkańców Wolnego Miasta Krakowa trzeba by wykupić”. Kolejnym rozwiązaniem, którego żadną miarą Meciszewski nie mógł zaakceptować, było wypożyczanie przez bank pieniędzy w ok. 2/3 częściach realnego oszacowania (taka część zabezpieczenia miała być podstawą obliczenia kosztów udzielenia kredytu, czyli oprocentowania, stanowiącego zysk banku). Rozwiązanie takowe było dopuszczalne w przypadku „banków miłosierdzia", które miały zapobiegać nędzy, ale nie w instytucjach kredytowych: banki owe udzielając jałmużny nie spodziewają się zysku, ale już Bank Krajowy „powinien rozprzestrzeniać obieg, pobierając znaczne opłaty”. Za skandaliczny uznał Meciszewski warunek uzyskania poręczenia Kongregacji Kupieckiej przy udzielaniu pożyczek na weksle kupców. Rozwiązanie takie nie było praktykowa- 
ne w Anglii i Francji, gdzie przy dyskontowaniu weksli zagranicznych wystarczające było poręczenie dwóch indosantów. Meciszewski przekonywał, że niemożliwe jest uchronienie przedsiębiorstw spekulacyjnych od groźby straty. Sprzeciwiał się również utworzeniu Towarzystwa Kredytowego Hipotecznego, przywilejowi egzekucji administracyjnej (której podlegały jedynie podatki stałe) oraz ,wyłączeniu pretensji Banku spod powagi sądów miejscowych". W jego ocenie, nieuzasadnione były też nadzieje Hallera związane z nadzorem komisarza, bo nawet posiadanie odpowiednich kwalifikacji oraz wpłacenie kaucji „nijak się miało do ogromu odpowiedzialności, która na nim ciąży”. Dla członków Komitetu Bankowego, do których w pierwszym rzędzie kierował swoje wystąpienie, oczywisty musiał być zły stan gospodarki Wolnego Miasta, monopol pieniężny był więc niepożądany ${ }^{61}$.

Meciszewski zrezygnował ze szczegółowej analizy poszczególnych rozwiązań propozycji Hallera, twierdząc, że gdy ,zasady są szkodliwe, nie ma sensu poprawianie prawideł miejscowych" (zasady zwoływania zgromadzenia ogólnego, wybór dyrektorów, kwalifikacje urzędników, statut banku, zatrzymanie wadium). Wbrew twierdzeniom Hallera, ,nie wszystko co do uskutecznienia łatwe, korzystne dla Kraju być może" (czyli powołanie banku prywatnego; jego utworzenie nie było celowe nawet $\mathrm{w}$ razie nie doprowadzenia do skutku idei banku rządowego); Meciszewski zbijał też argument braku pieniędzy w Skarbie Publicznym (,fundusze rządowe są niewyczerpane, chociaż ich na pogotowiu nie ma”), Senat i parlament mogły też liczyć na poparcie społeczne: Meciszewski sugerował zatroszczenie się, aby „przedsięwzięcie takowe z jak największym oszczędzeniem ofiar ze strony Obywateli przywieść do skutku można" (dobrym przykładem była budowa kanałów prywatnych w 1833 r.: niezbędne środki przyniósł podatek konsumpcyjny od rzezi bydła ${ }^{62}$ ). Meciszewski nie podzielał obaw dotyczących ogołocenia Wolnego Miasta z pieniędzy wskutek monopolistycznej działalności banku rządowego, w tym „mnożenia masy pieniędzy poprzez papier je wyobrażający”. Najlepszym dowodem były ewidentne korzyści z działalności Banku Polskiego w Królestwie Polskim. Zaprzeczał też, aby w jego projekcie pojawiło się przyzwolenie na praktyki monopolistyczne: wręcz przeciwnie, proponował wprowadzenie zakazu handlu cząstkowego przez Bank Krajowy. Meciszewski twierdził, że utworzenie banku rządowego przyczyni się do „wypędzenia z Kraju lichwiarzy”, którzy „z założonymi rękami próżniackie pędząc życie, niezasłużo-

${ }^{61}$ H. Meciszewski, Uwagi nad projektem do ustanowienia $w$ Wolnym Mieście Krakowie z Okręiem Banku Publicznego Prywatnego z akcyonaryuszów złożonego..., s. 17-18, 20-21, 23-24, 26-27, 29-33, 35-37. Meciszewski przekonywał, że „prywatne stowarzyszenia handlowe” w ogóle nie powinny się znajdować w sferze zainteresowania władzy prawodawczej.

${ }^{62}$ Ustawa z 7 IX 1833 r. O funduszu na budowe prywatnych kanałów, ogłoszona pismem Senatu Rządz. nr 5953 DGS, Dz. Praw WMK z 1833 roku. Ustawa weszła w życie 1 I 1833 r. 
ne cudzą pracą gromadzą majątki, a będąc zakałą moralności, zarazą towarzystwa, stają się przyczyną niezasłużonej ruiny przemysłem pracującego człowieka”. Co więcej, jak twierdził Meciszewski, ,niezalegałoby rynku naszego brudne i cuchnące żydostwo, czatujące na ofiary nieświadomości lub potrzeby". Dzięki bankowi rządowemu, korzystnemu dla „zabiegłego kupca, obracającego swym kapitałem w pracy i znoju”, a także ,pracowitego i posiadającego własne kapitały rzemieślnika”, do Krakowa „przybędą kapitaliści, dając poklask zbawiennym zamiarom Rządu”. Ponadto, „korzystne działania banku spowodują produkcję kapitałów, a nie ogołocenie Kraju z pieniędzy". Zdaniem autora, paradoksalny byłby wniosek przeciwny, że „w przypadku niekorzystnych działań banku, doszłoby do napływu kapitałów i rozwoju banku”. Meciszewski zarzucił swemu adwersarzowi niedokładne przedstawienie etapów kreowania banków rządowych w innych państwach. Przykładowo w Królestwie Polskim to nie monarcha wyasygnował środki ze swojej kieszeni, lecz rozpisana została pożyczka publiczna (uzyskana w domu handlowym Fraenkla, w wysokości $48 \mathrm{mln}$ złp), „na uposażenie instytucji”, będąca jeszcze jedną operacją finansową. Odnośnie rzekomego „wysysania przez Rząd pieniędzy, jak w Egipcie”, Meciszewski uznał za nieuzasadnione porównywanie położenia Wolnego Miasta do sytuacji krajów egzotycznych. Przekonywał, że „bank zaprowadzany dla korzyści wszystkich, nie jest monopolistą”. Odnośnie twierdzenia Hallera, że bank prywatny zapewnia identyczne korzyści jak rządowy, a dodatkowo poprawi sytuację finansów publicznych, gdyż „dochody Rządu są w kieszeniach Obywateli”, Meciszewski pytał, kim są obywatele krajowi? Wszakże „na fundusze krajowe składają się rolnicy, kupcy i rzemieślnicy”, kapitaliści zaś jedynie w niewielkim stopniu, a przecież to oni byliby głównymi beneficjentami banku prywatnego. Jedynie bank rządowy mogł ,zapewnić rozwój wszystkich przedsiębiorstw przemysłowych, przyczynić się do pomnożenia dochodów, a nie drenowania obywateli”. Meciszewski zajął się również problemem administrowania bankiem przez urzędników. Nieuzasadnione były obawy Hallera w tej mierze jako że podlegali oni nadzorowi Zgromadzenia Reprezentantów, czyli „reprezentacji społeczności, będącej bezpośrednim właścicielem kapitału”. W ogóle zarzuty pod adresem urzędników były niedopuszczalne, ,za nadto ubliżając wzniosłemu powołaniu urzędowania publicznego". Kolejny zarzut Hallera dotyczył zaniedbania innych dziedzin gospodarki, wskutek gromadzenia kapitałów jedynie na uruchomienie banku rządowego. Meciszewski dowodził, że dotychczasowe sposoby przeznaczenia środków publicznych powinny ustąpić przed koniecznością utworzenia Banku Krajowego, zresztą w dziejach Wolnego Miasta zawsze pojawiały się ,pewne wydatki nie do końca uzasadnione” (np. 300 tys. złp na remont Sukiennic, remont kościoła św. Katarzyny). Haller twierdził też, że przy banku prywatnym „Kraj nic nie ryzykuje” (chyba żeby chciał zostać akcjonariuszem). Meciszewski wskazywał jednak, że również dla banku prywatnego 
przewidywana była rękojmia rządowa, przyjmowanie asygnat itd. Nie zebranie wystarczającej ilości kapitałów będzie dowodem nie „braku zapotrzebowania i kapitałów”, ale potwierdzeniem „niemoralnych praktyk kapitalistów”, pobierających $12,18,40 \%$ od pożyczanych pieniędzy. Meciszewski przypomniał też szyderstwa Hallera z utworzenia w Krakowie drugiego Eldorado: czy jednak ważniejsza nie była „najmniejsza poprawa losu mieszkańców”? Haller nie ustosunkował się też do zarzutu, że chce dla swojego banku poręczenia rządowego, „bez rękojmi towarzystwa" ${ }^{\prime 3}$.

Warto dodać, że Meciszewski nie był zwolennikiem rozwiązań wprowadzonych w rewolucyjnej Francji. W jego ocenie asygnaty okazały się bezwartościowe, czego powodem był stosowanie sztywnego kursu (,kapitalista grzebał gotowiznę w ziemi, piekarz wyrzekał się swego zawodu, a rolnik wolał niszczyć swoje płody lub iść na rusztowanie"). Nie przekonywały go również działania podejmowane przez rząd pruski i austriacki, w okresie głodu i innych zaburzeń (,ostatecznie dostarczały one żywność najuboższym ze swoich zapasów, aby zapobiec nędzy”). Dla Meciszewskiego ważne było też zwalczanie lichwy, co należało do trudnych zadań, gdyż jak twierdził, „potrzeba jest matką największych zbrodni”. Kładł też nacisk na bardziej aktywną postawę rządu, we wspieraniu „towarzystw mających na celu pomoc ogółowi”"64.

Mimo niewątpliwych trudności, Meciszewski dostrzegał duży potencjał ekonomiczny Rzeczypospolitej Krakowskiej ${ }^{65}$. Nadzieję przynosiły zwłaszcza korzystne układy handlowe, podpisywane z krajami sąsiednimi. W tym miejscu należy wymienić pochodzący z 7 sierpnia 1823 r. traktat z Królestwem Polskim, dotyczący m.in. „wolnego wprowadzania fabrykatów”, który prolongowano, na

${ }^{63}$ H. Meciszewski, Uwagi nad projektem do ustanowienia $w$ Wolnym Mieście Krakowie z Okręgiem Banku Publicznego Prywatnego z akcyonaryuszów złożonego..., s. 39-51, 54-60. Meciszewski stwierdził, że koncepcja banku Hallera była ,pomysłem,w który bym nie uwierzył, gdybym go nie miał przed sobą".

${ }^{64}$ H. Meciszewski, O potrzebie i użyteczności zaprowadzenia Banku..., s. 12-13. W Wolnym Mieście „stowarzyszenia prywatne” były zbyt słabe. Faktem była „, trudnością wlekąca się egzystencja włościan, kupców i rzemieślników”.

${ }^{65}$ Warto zwrócić uwagę, że na mocy decyzji kongresu wiedeńskiego Wolnemu Miastu przysługiwały przywileje handlowe, czyniące z niego miasto wolnocłowe. Kraków odzyskał na krótko pomyślność gospodarczą, dźwigając się z XVIII-wiecznego upadku. Zarazem masowy napływ towarów z zewnątrz utrudniał rozwój produkcji na szerszą skalę, a możliwości eksportowe były bardzo ograniczone. Z nowszych prac zob. K. Meus, Wolne Miasto Kraków-przykład monokultury gospodarczej [w:] J. Wyrozumski (red.), Rzeczpospolita Krakowska 1815-1846. Materiaty z sesji naukowej 23 maja 2015 roku, Kraków 2016, s. 29-54 (zwł. s. 29-31); T. Gąsowski, Rzeczpospolita Krakowska-ostatni skarawek wolnej Polski [w:] M. Stankiewicz-Kopeć, T. Budrewicz (red.), Narodziny Rzeczypospolitej Krakowskiej. Relacje - obrazy - wspomnienia, Kraków 2016, s. 24-25; J.M. Małecki, Rozwój czy zastój? Kraków 1796-1866 [w:] J. Wyrozumski (red.), Kraków. Nowe studia nad rozwojem miasta, Kraków 2007, s. 589-594. 
mniej korzystnych warunkach, 1 lipca 1834 r. ${ }^{66}$ Jak już powiedziano, dla Meciszewskiego podstawowym problemem „brak kapitałów i ludzi przemyślnych”. Niezbędne było więc „obniżenie ceny pieniędzy i ożywienie łatwości ich ruchu”, możliwe jedynie poprzez tani kredyt publiczny, który „pilnuje surowo małego swego, lecz prawego zysku"67.

\section{DZIAŁALNOŚĆ KOMITETU BANKOWEGO}

Jak wspomniano, na podstawie art. 159 statutu sejmowego, projekt Meciszewskiego trafił pod rozwagę Senatu (parlamentarzyści zarekomendowali go jako pomysł „godny inicjatywy”). Rząd przyznał, że nieobecność banku w życiu gospodarczym Wolnego Miasta stanowi istotny „uszczerbek dobra publicznego”, istotnie wpływający (w dziedzinie przemysłu i handlu) na "stagnację i odrętwienie wszystkiego w Kraju". Dlatego polecił parlamentowi wybranie Komitetu Bankowego, który miał przeanalizować poszczególne tezy projektu ${ }^{68}$.

Oprócz Hallera, w jego skład weszli senatorowie J. Mieroszewski (przewodniczący) i W. Like, zastępca senatora T. Konopka, a także delegaci sejmu (H. Meciszewski, F. Lipczyński, A. Czapski, J.K. Piechocki i J. Szembek). Z wynikami prac komitetu miało się zapoznawać Zgromadzenie Reprezentantów ${ }^{69}$. Jeszcze na pierwszym posiedzeniu komitetu pojawiła się propozycja, by dokooptować do niego „osoby mające doświadczenie w profesji handlowej”. Niebawem Senat zgodził się na powołanie Antoniego Helcla (Holtzla), Jana Wentzla, Pawła Czajkowskiego, Stanisława Boguńskiego i Leona Bochenka, jako „obywateli światłych i znanych z zamiłowania dobra powszechnego"70.

${ }^{66}$ J. Bieniarzówna, J.M. Małecki, Dzieje Krakowa..., s. 110-113; S. Wachholz, Rzeczpospolita Krakowska. Okres od 1815 do 1830 r., Warszawa 1957, s. 104-105. Umowa handlowa obowiązywała do $31 \mathrm{~V} 1843$. W 1844 r. wynegocjowano traktat handlowy z cesarstwem austriackim. W. Kopff, Wspomnienia z ostatnich lat..., s. 44-45.

${ }^{67}$ H. Meciszewski, O potrzebie i użyteczności zaprowadzenia Banku..., s. 14-16. Meciszewski pisał też o takowym kredycie, że ,rumieni go korzyść podejrzana i potrzeba wymuszona, ale się cieszy, gdy obok zapewnienia swojej należytości, odpłacający mu daninę, własnych przysparza dostatków”. I dalej: „dzięki niemu zawita do nas ruch, obfitość i taniość pieniędzy, zagnieździ się przemysł, a w skutku tego handel zakwitnie, powab zaś handlu i przemysłu przywabi na ziemię naszą tysiące rąk pracowitych, który zaludni pustkami stojące domy, wywoła nieznane i odłogiem leżące gałęzie wyrobów krajowych".

${ }^{68}$ Ibidem, s. 11. Komitet miał „Zgłębić projekt” Meciszewskiego, a następnie „przepisać organizację" Banku Krajowego.

${ }_{69}$ Pismo Senatu Rządz. do Wydziału Dochodów Publicznych, J. Mieroszewskiego, J. Hallera, W. Like, T. Konopki, H. Meciszewskiego, F. Lipczyńskiego, A. Czapskiego, J. Piechockiego i J. Szembeka z 3 I 1834 nr 36, WMK V-202, k. 381.

${ }^{70}$ Pismo H. Meciszewskiego do Senatu Rządz. z 24 XII 1834, WMK V-202, k. 375-376; Pismo Senatu Rządz. do J. Mieroszewskiego, A. Holtzla, J. Wentzla, P. Czajkowskiego, S. Boguńskie- 
15 grudnia 1834 r. na forum komitetu wystąpił Meciszewski. Ponownie ujawnił swoje zapatrywania, dotyczące m.in. organizacji i form działalności przyszłego banku, rządowego czy też prywatnego. Ponieważ w tej kluczowej kwestii zdania członków komitetu były podzielone, Meciszewski, chcąc ułatwić im wydanie „,bezstronnego sądu”, raz jeszcze stwierdził, że bank państwowy lepiej przystaje do warunków panujących w Rzeczypospolitej Krakowskiej (zapewnia „więcej korzyści dla kraju" $)^{71}$.

15 stycznia 1835 r. większością głosów 6:5 komitet podjął uchwałę o zasilaniu Banku Krajowego z sum laudamialnych, stanowiących własność rządu Wolnego Miasta ${ }^{72}$. Należy wspomnieć, że w tym samym czasie na forum komitetu głos ponownie zabrał Meciszewski. Przy okazji debaty nad uruchomieniem banku, oprócz wyrażenia oczywistej opinii, że kluczową rolę w wymianie handlowej odgrywa złoto i srebro, a „kredyt publiczny jest duszą handlu, czyli zamiany”, dogłębnie scharakteryzował trzy, omówione wyżej, sposoby finansowania banku ${ }^{73}$.

Zdaniem znawczyni dziejów Krakowa, Komitet Bankowy prowadził ożywioną działalność, zaś jego prace cieszyły się wśród mieszkańców Krakowa sporym zainteresowaniem ${ }^{74}$. Idea banku skłaniała też do działania Senat, który pod koniec 1834 r. nakazał wójtom rozpowszechnienie projektu wśród Krakowian oraz mieszkańców gmin okręgowych ${ }^{75}$.

\section{PROJEKTY JULIUSZA FLORKIEWICZA I SEBASTIANA GIDLIŃSKIEGO}

Wypada również odnotować, że pomysł utworzenia banku miał jeszcze innych propagatorów. Należał do nich m.in. Juliusz Florkiewicz ${ }^{76}$, zachęcajacy mieszkańców Krakowa do ocknięcia się z apatii i podjęcia zdrowej inicjatywy, mającej na celu podźwignięcie bytu materialnego miasta ${ }^{77}$. W 1837 r. wydał on

go, L. Bochenka, H. Meciszewskiego z 27 XII 1834 nr 7676, ibidem; K. Bąkowski, Kronika Krakowska 1796-1848, cz. III: od r. 1832 do 1848, „Biblioteka Krakowska” nr 42, Kraków 1909, s. 63.

${ }^{71}$ H. Meciszewski, O potrzebie i użyteczności zaprowadzenia Banku..., s. 8-11. Oceniał, że założenie Banku Krajowego jest ważniejsze od ,upięknienia miasta, Loterii, Sukiennic i innych przedsięwzięć”, stanowi bowiem gwarancję realizacji podstawowego zadania rządu, jakim jest „dbałość o dobre mienie, bogactwo i pomyślność ogółu".

${ }^{72}$ H. Meciszewski, O potrzebie i sposobach uposażenia Banku Publicznego..., s. I.

${ }_{73}$ H. Meciszewski, O potrzebie i sposobach uposażenia Banku Publicznego..., s. 25-37.

74 J. Bieniarzówna, Z dziejów liberalnego i konspiracyjnego..., s. 33.

75 Pismo Senatu Rządz. do wójtów gmin okręgowych z 11 XI 1834 nr 6474, WMK V-202, k. 377. Każdy wójt otrzymał 6 egzemplarzy projektu.

76 Jego biografia zob. J. Brzózka, Dzieje rodziny Florkiewiczów herbu Ozdoba z Młoszowej w XIX wieku, „Biblioteka Krakowska” nr 148, Kraków 2006, passim.

77 J. Bieniarzówna, $Z$ dziejów liberalnego i konspiracyjnego..., s. 33; J. Brzózka, op.cit., s. $127-128$. 
niewielką książeczkę, w której przekonywał, że dla pomyślnego rozwoju kraju konieczne jest, aby „system administracyjny postawił się w sferze postępu, zaszczepiając te instytucje, których korzystny wpływ na siły produkcyjne kraju nie może dłużej być wątpliwym”. W tym miejscu chodziło mu o „bank cyrkulacyjny”, który stanowił „duszę każdego ruchu materialnego” oraz podstawę rozwoju gospodarczego. Pod pojęciem banku publicznego Florkiewicz rozumiał nie tylko instytucje rządową, ale każdy bank wypuszczający bilety „mające kurs upowszechniony w kraju”. Bank publiczny mógł występować pod postacią banku rządowego bądź akcyjnego, tworzonego przez akcjonariuszy; odróżniał je od banków prywatnych ${ }^{78}$.

Dalej Florkiewicz twierdził, że źródłem wszelkiego bogactwa jest produkcja, dla której rozwoju niezbędny jest kapitał. Domagał się powołania instytucji zdolnej „Zwiększyć całość kapitału narodowego” oraz dostarczyć kapitałów dla osób, które są go pozbawione, ale „mają chęć i możność produkowania”. W posiadanie pieniędzy można bowiem wejść na dwa sposoby: przez „zamianę swych wartości za pieniądze" oraz za pośrednictwem kredytu (czyli poprzez pożyczkę pieniędzy); rozwój przemysłu jest zaś możliwy poprzez pracę prostą bądź „pracę skombinowaną, czyli wspartą na kredycie". Głosił, że kapitał narodowy, powiększony dzięki kredytom, może rozwijać swoje siły produkcyjne; kapitał działa jako narzędzie produkcyjne, stymulując „użyteczne zatrudnienie większej ilości osób, gdyż nowy kapitał wymaga nowej pracy"; spotęgowanie rozwoju gospodarczego jest możliwe dzięki temu, że rozwój jednej gałęzi wpływa na inne. Wśród powodów braku kapitału w Wolnym Mieście Florkiewicz widział niekorzystny bilans handlowy, w tym wyrównywanie deficytu poprzez „eksport gotówki”. Środkiem zaradczym była dla niego intensyfikacja produkcji oraz wprowadzenie instytucji, która pozwalałaby na zastępowanie pieniędzy metalowych - kredytowymi. W jego ujęciu, założenie banku rodziło następujące korzyści: a) pomnożenie kapitału narodowego; b) obniżenie stóp procentowych; c) rozwój przemysłu; d) likwidacja deficytu w obrocie handlowym z zagranicą; e) zapobieganie odpływowi pieniądza; f) zapobieganie spadkowi cen wyrobów miejscowych ${ }^{79}$.

78 J. Florkiewicz, Potrzeba zakładania banków publicznych, ich korzyści i operacye w ścistym zastosowaniu do stanu materyalnego Wolnego Miasta Krakowa z okręgiem, Kraków 1837, s. 3-7. Twierdził też, że każdy człowiek ma „potrzeby moralne i fizyczne”, przyznając, że ,potrzeby materialne silnie przeważną rolę odgrywają w życiu człowieka”; dostrzegał wyraźny wzrost zainteresowania ekonomią polityczną oraz „teorią gospodarstwa krajowego”; oceniał, że „to, co wczoraj było zbytkiem, należy dzisiaj do zaspokojenia pierwszych potrzeb".

79 Ibidem, s. 8-9, 12-14, 19-21, 24-27. Wedle informacji zamieszczonych w broszurce, Florkiewicz był członkiem-korespondentem Francuskiego Towarzystwa Statystyki Uniwersalnej oraz Paryskiej Akademii Przemysłu Rolniczego, Rękodzielnego i Handlowego. Potwierdza to J. Brzózka, op.cit., s. 134-135. 
Można wspomnieć, że w drugiej części swego dzieła Florkiewicz zawarł charakterystykę najważniejszych operacji bankowych, omówił także działalność banków w różnych krajach. Dowodzil, że zasadniczo jest ona powiązana z trzema głównymi rodzajami aktywności ludzkiej. Stąd powszechne występowanie następujących rodzajów kredytów: a) rolnicze; b) rękodzielnicze; c) handlowe ${ }^{80}$.

Florkiewicz zachęcał do precyzyjnego określenia zasad funkcjonowania banku oraz jego organizacji, w drodze statutu organicznego oraz ,innych wewnętrznych urządzeń". Wymienione akty prawne powinny określać wzajemne obowiązki banku i dłużników, kompetencje urzędników bankowych, podział ich czynności itp. Wbrew powszechnej opinii, przekonywał też, bilety bankowe nie mogą utracić wartości realnej i zawartego w nich „kredytu”. Po pierwsze dlatego, że rząd zapewnia ich wymienialność na „monetę brzęczącą”. Poza tym, ich wartość jest zagwarantowana: a) kapitałem zakładowym banku; b) zabezpieczeniem hipotecznym majątku banku (,hipoteczna wartość awansów na kredyt ziemski uczynionych"); c) gwarancjami ze strony fabrykantów; d) wartościami będącymi podstawą operacji kredytu handlowego; e) wartością zdeponowanych papierów publicznych, kosztowności, towarów itp. ${ }^{81}$

Z kronikarskiego obowiązku należy jeszcze odnotować udział w debacie Sebastiana Gidlińskiego, aplikanta Biura Rachuby. W swoim dziełku okazywał się on zwolennikiem giełdy, która „przy dobrej organizacji, może zatrudnić wiele kapitałów”. Wskazywał, że „ruch kapitałów rzeczywistych i urojonych”, widoczny chociażby na giełdach w Paryżu i Warszawie, odbywa się zawsze „z korzyścią dla ogółu miejscowych". Gidliński odwoływał się też do przykładów banków w Amsterdamie, Utrechcie, Hamburgu i Wenecji, jako instytucji dobrze spełniających powierzoną im rolę. Utrzymywał zarazem, że wypuszczenie w Rzeczypospolitej Krakowskiej „obligacji zabezpieczonych na dobrach narodowych bądź funduszach krajowych" jest jednak niewskazane. Szans Wolnego Miasta upatrywał w intensyfikacji pośrednictwa handlowego między „krajami południowymi i północnymi”, co powinno stać się przedmiotem zabiegów zwłaszcza ze strony Kongregacji Kupieckiej, również w drodze ,prywatnych negocjacji”. Krótko rzecz ujmując, utworzenie banku było dla niego koniecznością, lecz dopiero w razie uprzedniego zaprowadzenia w Krakowie giełdy ${ }^{82}$.

${ }^{80} \mathrm{~W}$ dziełku Florkiewicza znalazły się także definicje podstawowych pojęć ekonomicznych, w tym pracy, pieniądza, kapitału stałego i obiegowego, jak również najważniejszych terminów z zakresu bankowości (kredyt handlowy, eskonto weksli, awanse na złożone papiery publiczne, przechowywanie kosztowności, prowadzenie rachunków bieżących). Ibidem, s. 28-73.

${ }_{81}$ Szerzej zob. ibidem, s. 79-92.

${ }^{82}$ Pismo S. Gidlińskiego do Senatu Rządz. z 4 IX 1833 r., WMK V-202, k. 411-421. Zob. Tabella koleynego lossowania obligacyi sztuk 10000 corocznie po 1000 ztp, z których każdey wartość nominalna jest złp 10, ibidem, k. 419. Pierwszą urzędową giełdą towarowo-pieniężną była Giełda 


\section{FIASKO INICJATYW UTWORZENIA BANKU KRAJOWEGO}

Wracając do głównego nurtu prac nad utworzeniem Banku Krajowego, należy wskazać na dalsze poczynania Meciszewskiego, który na przełomie lat 1834 i 1835 rozpoczął, głównie za pośrednictwem broszur oraz artykułów prasowych, swoistą ofensywę propagandową. Na własny koszt zamierzał też udać się w podróż do Niemiec, Włoch, Francji i Wielkiej Brytanii, celem dokładniejszego przyjrzenia się organizacji tamtejszych banków (,rozpatrzenie się w tego gatunku zakładach"). Zwrócił się więc do Senatu, aby ten wyjednał u rezydentów „mocarstw opiekuńczych” zapewnienie opieki ze strony przedstawicielstw dyplomatycznych, co mogło w istotnym stopniu ,przyczynić się do osiągnięcia powyższego celu" "3. Uznając, że wnioskodawca „kieruje się dobrem publicznym”, rząd Wolnego Miasta wystosował więc apel do „wszystkich legacji i ambasad trzech Najjaśniejszych Dworów Krajem tutejszym opiekujących się" o udzielenie Meciszewskiemu wszelkiej niezbędnej pomocy ${ }^{84}$.

Oprócz celów poznawczych, podróż Meciszewskiego miała przede wszystkim ułatwić zorientowanie się w możliwościach uzyskania kredytu zagranicznego. Meciszewski chciał znaleźć bankiera, który byłby w stanie wyłożyć niebagatelną kwotę $1 \mathrm{mln}$ złp, niezbędną do uruchomienia Banku Krajowego. Świadczyło to pośrednio o fiasku nadziei związanych z jego sfinansowaniem ze środków Wolnego Miasta ${ }^{85}$. Pamiętać należy w tym miejscu o uchwale Komitetu Bankowego z 15 stycznia $1835^{86}$.

W trakcie pobytu w Wiedniu, Meciszewski skorzystał z pośrednictwa Wacława Krasnopolskiego-Gottesmanna, zobowiązując go do nawiązania kontaktów z „bankierami i osobami znakomitymi”, gotowymi „sumy w obwodzie Wolnego Miasta Krakowa zahipotekowane, około milion złp wynoszące, dla założenia tymże kapitałem banku nacjonalnego, zakupić". Początkowo wydawało się, że misja Meciszewskiego zostanie uwieńczona powodzeniem: Krasnopolski znalazł „znakomitą osobę”, która zgodziła się, „bez najmniejszej szkody i uciążliwości dłużników”, na „przeniesienie w gotowiźnie” wymaganej kwoty, w ciągu 3 miesięcy. Warunkiem było jednak uzyskanie zgody rządów Austrii, Rosji i Prus („tamtejszych rządów”), o której otrzymaniu Meciszewski miał powiadomił swo-

Kupiecka Warszawska (1817 r.). B. Marks, Giełdy na ziemiach polskich pod zaborami (1817-1918) [w:] J. Chumiński, K. Popiński (red.), Gospodarcze i społeczne skutki zaborów Polski, Wrocław 2008, s. 221-222.

${ }^{83}$ Pismo H. Meciszewskiego do Senatu Rządz. z 6 II 1835 (do nr 847), WMK V-202, k. 371.

${ }^{84}$ Pismo Senatu Rządz. do rezydentów Trzech Mocarstw Protegujących z 10 II 1835, WMK V-202, k. 369.

${ }^{85}$ J. Bieniarzówna, Z dziejów liberalnego i konspiracyjnego..., s. 33-34; Z. Jabłoński, op.cit., s. 359 .

${ }^{86}$ Zob. przyp. 72. 
jego partnera w rozmowach. Zgoda jednak nigdy nie nadeszła, wiedeński pośrednik złożył na Meciszewskiego skargę, że ten „słowem kawalerskim zapewniał, że nie ma przeszkód do zawarcia tegoż interesu" ${ }^{\prime 7}$.

W pochodzącym z wiosny 1835 r. raporcie Wydziału Spraw Wewnętrznych stwierdzono, że Meciszewski „wdał się w rozmowy dotyczące finansowania banku przynajmniej niewłaściwie”. Nie posiadał bowiem upoważnienia do prowadzenia „układów w sprawie odstąpienia sum laudamialnych”, czyli zabezpieczenia pożyczki na dobrach w okręgu krakowskim. Co ważniejsze, nie podjęto jeszcze w ogóle decyzji o utworzenie Banku Krajowego. Konieczne było więc natychmiastowe zerwanie negocjacji ${ }^{88}$.

W powyższej sprawie Senat wypełnił po prostu wolę „Trzech Najjaśniejszych Dworów". Sprawa Banku Krajowego została bowiem utrącona na zjeździe monarchów w Cieplicach 2 (14) października 1835 r. Mikołaj I, Ferdynand „Dobrotliwy” oraz Fryderyk Wilhelm III podjęli decyzję o storpedowaniu krakowskiej inicjatywy. Aczkolwiek parafowany traktat dotyczył w pierwszym rzędzie podtrzymania współpracy Świętego Przymierza, znalazła się w nim też zapowiedź likwidacji Rzeczypospolitej Krakowskiej. W jego punkcie 2 stwierdzono zaś, że „Dwory nie dozwolą założenia w Krakowie projektowanego banku, który stać się może potężnym środkiem działania w rękach sprawców zamieszek" ${ }^{" 9}$. Traktat potwierdzający cieplickie ustalenia podpisano ostatecznie w Berlinie 14 października 1835 r. ${ }^{90}$.

Co zaskakujące, o okolicznościach zniweczenia idei Banku Krajowego nie wspomina Meciszewski w swoim raporcie na temat sytuacji w WMK, skierowanym do opinii publicznej i rządów krajów Europy zachodniej; milczą w tej sprawie również poddane analizie protokoły posiedzeń Senatu ${ }^{91}$. Antoni Tessarczyk

${ }^{87}$ Pismo Krasnopolskiego-Gottesmanna do Senatu Rządz. z 10 III 1835 r. (do nr 1767), WMK V-202, k. 363-364. Krasnopolski był obywatelem galicyjskim, pracował w kancelarii urzędniczej w Wiedniu (mieszkał przy Leopoldplatz 579).

${ }_{88}$ Pismo Wydz. Dochodów Publicznych (J. Haller i W. Like) do Senatu Rządz. z 6 IV 1835 r., WMK V-202, k. 441; Pismo Senatu Rządz. do Krasnopolskiego z 8 IV 1835 r., ibidem. O zerwaniu rozmów Krasnopolskiego miał powiadomić pełnomocnik Senatu, Westbuhely. Senat nie miał bowiem zamiaru „wchodzić w żadne układy dotyczące odstąpienia kapitałów ze Skarbu Publicznego, wypożyczonych osobom prywatnym".

89 J. Bieniarzówna, op.cit., s. 34; H. Lisicki, Antoni Zygmunt Helcel 1808-1870, Lwów 1882, t. I, s. 8587. Konwencję sygnowali: rosyjski kanclerz Karol Robert Nesselrode (1780-1862), austriacki kanclerz Klemens Metternich (1773-1859) oraz pruski minister Ancillon.

${ }^{90}$ Tajny traktat o wcieleniu Krakowa do Austrii (1835) [w:] Rzeczpospolita Krakowska 1815-1846. Wybór źródet..., s. 345. Autorka podaje fragment konwencji w nieco innym brzemieniu: „trzy Dwory sprzeciwią się wykonaniu projektu, który od niejakiego czasu powstał w Krakowie, utworzenia tamże banku, ponieważ taka instytucja mogłaby się stać potężnym środkiem akcji w ręku sprawców zamieszek".

${ }^{91}$ H. Meciszewski [L. Królikowski], Memoriat historyczny i polityczny o stanie obecnym Wolnego Miasta Krakowa i Jego Okręu na poparcie adresu obywateli krakowskich podanego rzadowi 
wskazuje, że udzieloną Florkiewiczowi kategoryczną odmowę założenia banku Senat oparł na wyraźnym zakazie Konferencji Rezydentów; głównym oponentem był rezydent austriacki, który mając świadomość planowanego wcielenia Wolnego Miasta do reprezentowanego przez siebie kraju, nie chciał doprowadzić do kolizji narodowego banku Austrii z bankiem krakowskim ${ }^{92}$.

W 1837 r. Wydział Dochodów Publicznych powiadomił Senat, że na podstawie akt archiwalnych nie jest w stanie ustalić, czy Komitet Bankowy opracował własny projekt Banku Krajowego. Stwierdzał też, że jeżeli „sprawa jest jeszcze aktualna", należałoby wezwać jego członków do przyspieszenia prac, a także uzupełnić skład, z którego „ubyły już cztery osoby”. Wniosek wydziałowy był rozpatrywany na posiedzeniu rządu. Sprawę jako nieaktualną zwrócono jednak do Archiwum Głównego ${ }^{93}$.

\title{
THE NATIONAL BANK OF THE FREE CITY OF CRACOW. CHARACTERIZATION OF THE ATTEMPTS TO CREATE IT BETWEEN 1833 AND 1835
}

\begin{abstract}
The following article presents the attempts of the authorities of the Free City of Cracow to form the so-called National Bank. The presented topic was not analyzed hitherto in scientific literature. Consequently, sources of key importance necessary to formulate this research paper were taken from the collection stored at the National Archive in Cracow. The most crucial sources which have to be mentioned are the so-called senate acts. These documents constitute the legacy of the activity of the Governing Senate which had "the supreme administrative authority" (facsimile 88 "Coins 1816-1853" [Polish Monety 1816-1853], signed FCC V-202) in the Republic of Cracow. Minutes of the meetings of the Assembly of Representatives (the sejm of the Free City of Cracow) as well as their correspondence with the government were also acquired from the "The Archive of the Free City of Cracow" collection. Furthermore, special attention is paid to treaties composed by two authors, Hilary Meciszewski and Józef Haller, who were great proponents of the National Bank concept. The treaties were printed between 1834 and 1835. Moreover, legal publications ("Journal of Rights of the Free City of Cracow" [Polish Dziennik Praw

francuskiemu i angielskiemu w październiku 1839 roku, Paryż 1840. Memoriał miał spowodować poruszenie tamtejszej opinii publicznej i wstawienie się parlamentów w sprawie Wolnego Miasta Krakowa.

${ }^{92}$ A. Tessarczyk, Rzeczpospolita Krakowska wolna, niepodległa i ściśle neutralna, pod opieka trzech wielkich mocarstw: Austrii, Prus i Rosji, a za rękojmią kongresu wiedeńskiego (1815-1846), Kraków 1863-1870, s. 248.

${ }^{3}$ Pismo Archiwum Głównego do Senatu Rządz. z 14 XI 1837 nr 88 WMK V-202, k. 361-362; Pismo Wydz. Dochodów Publicznych do Senatu Rządz. z 18 XI 1837 (do nr 6755 DGS), ibidem; notatka referenta Wydz. Dochodów Publicznych (J. Księżarski), ibidem, k. 359. Dyskusja na forum senackim odbyła się 22 XI 1837 (nr obrad 3941).
\end{abstract}


$W M K$ ], "Government Journal" [Polish Dziennik Rzadowy]) as well as the Cracow press played a significant part. And finally, articles devoted to the history of banking on Polish lands in the $19^{\text {th }}$ century are also taken into consideration.

\section{BANQUE NATIONALE DE LA VILLE LIBRE DE CRACOVIE. LES TENTATIVES INFRUCTUEUSES DE LA CREER EN 1833-1835}

\section{Resumé}

Cet article met en lumière les efforts déployés par les autorités de la ville libre de Cracovie pour créer la soi-disant Banque nationale. Cette question n'a pas été analysée dans la littérature scientifique, alors, les documents sources faisant partie des collections des Archives nationales de Cracovie ont eu l'importance capitale dans l'élaboration de l'article. En particulier, les soi-disant dossiers du Sénat, reflétant l'activité du Sénat qui exerçait « le pouvoir administratif suprême » de la République de Cracovie (fasc. 88 „Monety 1816-1853", réf. WMK V-202), méritent l'attention. Les procès-verbaux des réunions de 1'Assemblée des représentants (parlement de la WMK [Ville libre de Cracovie - VLdC) et sa correspondance avec le gouvernement proviennent également des collections des «Archives de la Ville libre de Cracovie ». Une attention particulière a été accordée aux traités de deux auteurs: Hilary Meciszewski et Józef Haller qui ont été les principaux partisans de l'idée de la Banque nationale. Leurs traités ont été publiés en 1834-1835. Les revues juridiques (« Dziennik Praw WMK » [Journal des lois de VLdC], « Dziennik Rządowy » [Journal gouvernemental]) et la presse de Cracovie ont également joué un rôle important. En outre, des études sur l'histoire des banques en territoires polonais au XIX ${ }^{\mathrm{e}}$ siècle ont été prises en compte. 